\title{
Checklist of freshwater fishes from Loreto, Peru
}

\author{
Lista de especies de peces de agua dulce de Loreto, Perú
}

\author{
Vanessa Meza-Vargas*1,2 \\ https://orcid.org/0000-0002-1041-1271 \\ meza.sv@gmail.com \\ Dario R. Faustino-Fuster ${ }^{1,3}$ \\ https://orcid.org/0000-0002-1445-3495 \\ dariorff36@gmail.com \\ Junior Chuctaya ${ }^{1,3}$ \\ https://orcid.org/0000-0002-8876-4675 \\ junior.chuctaya@gmail.com

\section{Max Hidalgo 1} \\ https://orcid.org/0000-0002-0071-5159 \\ mhidalgod@unmsm.edu.pe \\ Hernán Ortega Torres ${ }^{1}$ \\ https://orcid.org/0000-0002-4396-2598 \\ tortegat@unmsm.edu.pe

\section{*Corresponding author}

1 Universidad Nacional Mayor de San Marcos, Museo de Historia Natural, Departamento de Ictiología, Av Arenales 1256, 15072, Lima, Perú.

2 Laboratório de Sistemática de Vertebrados, Pontifícia Universidade Católica do Rio Grande do Sul, Avenida Ipiranga 6681, 90619-900 Porto Alegre, RS, Brasil.

3 Departamento de Zoologia, Universidade Federal do Rio Grande do Sul, Programa de Pós-Graduação em Biologia Animal Av Bento Gonçalves, 9500, Bloco IV, Prédio 43433, Campus do Vale, Bairro Agronomia, Porto Alegre, RS, Brasil.

\section{Citación}

Meza-Vargas V, Faustino-Fuster DR, Chuctaya J, Hidalgo M, Ortega Torres H. 2021.Checklist of freshwater fishes from Loreto, Peru. Revista peruana de biología 28(especial): $\mathbf{e 2 1 9 1 1}$ 001- 028 (Diciembre 2021). doi: http://dx. doi.org/10.15381/rpb.v28iespecial.21911

\section{Presentado: $\quad 09 / 02 / 2021$

Aceptado: $\quad 10 / 08 / 2021$ \\ Publicado online: $30 / 12 / 2021$}

Editor: Leonardo Romero

\begin{abstract}
This study presents an extensive review of published and unpublished occurrence records of fish species in the Loreto department. Located in the northeast of the country, Loreto is the most geographically extensive region in the Peruvian territory. Despite the increase in fish collections in Loreto in recent years, the ichthyofauna of this department needs to be more documented. Based on a database of scientific collections and bibliographic information, an updated checklist of the freshwater fishes from Loreto is presented. The results reveal a rich and diversified ichthyofauna, with 873 species distributed in 331 genera, 50 families and 15 orders. The main groups are Characiformes (42.6\%), Siluriformes (34.8\%), Gymnotiformes (8.6\%) and Cichliformes (7.4\%). Part of the ichthyofauna has restricted distribution for Loreto (4.7\%). In addition, $9.0 \%$ of species from Loreto are used in fisheries. Meanwhile, 219 species $(25 \%)$ were categorized according to the IUCN criteria where only six species $(0.7 \%)$ are currently considered threatened species (CR, EN or VU). The results presented in this work indicate that this department needs more studies to know the biodiversity of fish, likewise, the information presented constitutes a contribution to the knowledge of fish diversity that would support environmental management actions and decision-making aimed at conserving one of the most diverse departments of Peru.
\end{abstract}

\section{Resumen}

Este trabajo presenta una revisión de los registros de especies de peces, publicados y no publicados, del departamento de Loreto. Localizado al noreste del país, Loreto es el departamento más extenso del territorio peruano. A pesar del incremento en el número de las colectas de peces en Loreto en años recientes, la ictiofauna de este departamento necesita ser más documentada. Sustentado en los registros en bases de datos de colecciones científicas e información bibliográfica, se presenta una actualización de la lista de peces de agua dulce de Loreto. Los resultados revelaron una ictiofauna rica y diversificada, con 873 especies, distribuidas en 331 géneros, 50 familias y 15 órdenes. Los principales taxones fueron Characiformes (42.6\%), Siluriformes (34.8\%), Gymnotiformes (8.6\%) y Cichliformes (7.4\%). Parte de la ictiofauna tiene distribución restricta para Loreto (4.7\%). Además, $9.0 \%$ de las especies son usadas en pesquerías de Loreto. Mientras tanto, 219 (25\%) especies fueron categorizadas de acuerdo con los criterios de la IUCN, donde sólo seis especies $(0.7 \%)$ son consideradas actualmente especies amenazadas (CR, EN o VU). Los resultados presentados en este trabajo señalan que este departamento necesita más estudios para conocer la biodiversidad de peces, así mismo, la información presentada constituye un aporte al conocimiento de la biodiversidad íctica que respaldarían las acciones de gestión ambiental y toma de decisiones destinados a conservar uno de los departamentos más diversos del Perú.

Keywords:

Amazon basin; ichthyofauna; Marañón River; species inventory; Ucayali River.

Palabras claves:

Cuenca del Amazonas; ictiofauna; río Marañón; inventario de especies; río Ucayali. 


\section{Introduction}

The Amazon drainage is the largest basin in the world and the major component of the Neotropical region. It includes a vast area of 7.3 million $\mathrm{km}^{2}$, crosses South America from the eastern Andes Mountains to the Atlantic coast crossing the shields of Brazil and Guyana (Venticinque et al. 2016, Leite \& Rogers 2013). Besides its vastness in area, the Amazon basin possesses distinct physiognomies formed by geological backgrounds, diversity of rivers and soils (Dagosta \& de Pinna 2018); and overall warm and humid Amazonian climate (Leite \& Rogers 2013). In turn, these factors are associated with an enormous diversity of flora and fauna, comprising the richest ecosystem on the planet (Dagosta \& de Pinna 2019).

The freshwater fish diversity of South America encompasses 5160 species; however, despite already being the most diverse freshwater ichthyofauna, estimates point to actual diversity between $8000-9000$ species (Reis et al. 2016). The Amazon basin harbors the highest fish diversity in the world with 2406 described species (Jézéquel et al. 2020). Several efforts have been made to describe species and update lists of species by countries (Ortega \& Vari 1986, Maldonado et al. 2008, Matamorros et al. 2009, Ortega et al. 2012, Mol et al. 2012, Le Bail et al. 2012, Barriga 2012, Angulo et al. 2013, Koerber \& Litz 2014, Sarmiento et al. 2014, Mirande \& Koerber 2015, Koerber et al. 2017, DoNascimiento et al. 2017) basins (Lasso et al. 2016, Ohara et al. 2017, Beltrão et al. 2019), regions (Jimenez-Prado et al. 2015, Van Der Sleen \& Albert 2017, Dagosta \& de Pinna 2019), and states (Bertaco et al. 2016, Dos Reis et al. 2020, Teixeira el al. 2020) along the Neotropical region.

The last checklist of freshwater native fishes from Peru registered 1064 species (Ortega et al. 2012), but with additions of new species, new records and taxonomic revisions, this diversity reached 1141 species (MINAM 2019). Peru is made up of 24 departments and a constitutional province (Callao); however, fish diversity studies were never carried out by department and the main fish checklists were directed to sub-basins, (Ortega et al. 2006, Rengifo 2007, Palacios et al. 2008, Carvalho et al. 2009, Correa \& Ortega 2010, Carvalho et al. 2011, Quezada et al. 2017, Armas et al. 2021).

Important ichthyological material deposited in peruvian fish collections comes from fieldwork associated to their environmental impact studies requested by law, to evaluate their potential impacts. In Loreto, some examples of these kind of activities are the exploration, exploitation, processing, and transportation of hydrocarbons (oil, gas) and Hidrovia projects. On the other hand, Rapid Biological Inventories conducted by the Field $\mathrm{Mu}$ seum during last 20 years have made possible to register the diversity from several areas in Loreto, particularly the fishes (Table 1).

Extensive biodiversity in Loreto is not limited to freshwater systems. Pitman et al. (2013) have done the first biodiversity compilation including plants and terrestrial vertebrates. As a result, Loreto has probably the highest species richness among Peruvian Departments, with 7959 plant species, 914 bird species, 267 mammal species, 216 amphibian species and 170 reptile species. Of these, the number of threatened species ranges between $1.7 \%$ (plants) to $7.5 \%$ (mammals) depending on the groups, and the number of endemics between $0.2 \%$ (birds) and 5.5\% (amphibian).

In contrast, the knowledge of fish diversity from Loreto is far from complete. By this point, it is an important task to be done. Accordingly, this study aims to provide the first checklist of freshwater fishes recorded in Lore-

Table 1. Previous fish inventories in different basins in Loreto. NP=National Park, NR=National Reserve, RAC=Regional area of conservation.

\begin{tabular}{|c|c|c|c|c|}
\hline Inventories & $\begin{array}{c}\text { Total } \\
\text { species }\end{array}$ & $\begin{array}{l}\text { Possible new } \\
\text { species }\end{array}$ & $\begin{array}{l}\text { Conservation } \\
\text { status }\end{array}$ & Reference \\
\hline Biabo Cordillera Azul & 93 & 10 & NP & de Rham, Hidalgo \& Ortega, 2001 \\
\hline Yavarí & 240 & 10 & & Ortega, Hidalgo \& Bértiz, 2003 \\
\hline Ampiyacu, Apayacu, Yaguas, Medio Putumayo & 207 & 5 & RAC & Hidalgo \& Olivera, 2004 \\
\hline Matsés & 177 & 9 & NR & Hidalgo \& Velásquez, 2006 \\
\hline Sierra del Divisor & 109 & 14 & NP & Hidalgo \& Pezzi, 2006 \\
\hline Nanay-Mazán-Arabela & 154 & 12 & RAC & Hidalgo \& Willink, 2007 \\
\hline Cuyabeno-Güeppí & 184 & 3 & NP & Hidalgo \& Rivadeneira, 2008 \\
\hline Maijuna & 132 & 7 & RAC & Hidalgo \& Sipión, 2010 \\
\hline Yaguas-Cotuhé & 337 & 7 & NP & Hidalgo \& Ortega-Lara, 2011 \\
\hline Cerros de Kampankis & 60 & 6 & & Quispe \& Hidalgo, 2012 \\
\hline Ere-Campuya-Algodón & 210 & 4 & & Maldonado-Ocampo, Quispe \& Hidalgo, 2013 \\
\hline Cordillera Escalera & 30 & 2 & & Hidalgo \& Aldea-Guevara, 2014 \\
\hline Tapiche-Blanco & 180 & 4 & & Corahua, Aldea-Guevara \& Hidalgo 2015 \\
\hline Medio Putumayo-Algodón & 232 & 12 & & Hidalgo \& Maldonado-Ocampo, 2016 \\
\hline Bajo Putumayo-Yaguas-Cotuhé & 150 & 2 & & Faustino-Fuster, Patarroyo \& de Souza, 2021 \\
\hline
\end{tabular}


to to improve scientific information for guiding policy and management decisions for conservation and fishery management.

\section{Material and methods}

Study area. - Loreto is the largest department in Peru located northeast of the country, representing 28\% of the Peruvian territory with an area of 368 851, 950 $\mathrm{km} 2$ (CONAM 2005). Its borders are with Ecuador in the northwest, with Colombia in the northeast, Brazil in the east, Amazonas and San Martin departments in the west, and the Ucayali department in the south (Fig. 1).

Loreto is part of the Amazon rainforest, belonging to the Amazon Lowland ecoregion (Abell et al. 2008) with remnants of the Andes in the west border, as well as the Cerros del Kampankins (Pitman et al. 2012), Cordillera Escalera (Pitman et al. 2014) and Cordillera Azul (Alverson et al. 2000). In the heart of the department, the Amazon River is formed by the confluence of Marañon and Ucayali rivers, close to Nauta City.

The Marañón River is born in the Andes, in the Raura snow peak in Pasco Department about more than 5800 meters above sea level ( $m$ a.s.l.). According to the elevation gradient, the Marañón River can be split into the upper and lower basin. The upper Marañón River flows from the Raura snow peak to the Manseriche Pongo at $190 \mathrm{~m}$ a.s.l., and from approximately the middle of this geomorphological zone this river flows crossing the Loreto region. The lower Marañón River comprises Manseriche Pongo as it joins with Ucayali River in Nauta City. The lower Marañón River flows from west to east in the Amazonian lowlands in Loreto, presenting a meandering channel, covered by sand and sparse rocks. During the flood season, it floods extensive areas frequently abandoning its old channel, opening a new one. The abandoned channels form the "cochas" lagoons or ox bow lakes, which - due to the shape they present - are called horseshoe lakes. The main tributaries of the lower Marañón River are Morona, Pastaza, Tigre, and Huallaga rivers (MINAM 2011).

The Ucayali River headwater is in the Eastern Andes, in the Mismi snow peak 5597 m a.s.l. in Arequipa, but is formally named by the junction of Urubamba and Tambo rivers, in the south of Ucayali Department. It can be separated into the upper and lower basin as well. The Upper Ucayali River flows from the Mismi snow peak to confluence between Ucayali and Pachitea rivers. The Lower Ucayali River goes from Pachitea River mouth to the confluence with Marañón River. The lower Ucayali River flows from south to north in Loreto; it also has meandering course forming "cochas" or lagoons and islands which constantly change shape and size. The tributaries of the lower Ucayali River are Aguaytia, Pisqui, Cushabatay and Tapiche rivers (MINAM 2011).

It is worth mentioning that both Lower Marañón and Ucayali rivers are navigable during the year. Once the Peruvian Amazon River is formed, it receives the contribution of tributaries like Nanay, Itaya, Napo, Ampiyacu-Apayacu, and Yavarí rivers (Peru); and Putumayo River (Colombia).

Data collection. - This study was based on bibliographic information. The record of species were obtained from collection data available on iDigBio (https://www.idigbio. org/portal/search), speciesLink (http://www.splink.org. $\underline{\mathrm{br} / \text { ) }}$ and mainly from Museo de Historia Natural, Universidad Nacional Mayor de San Marcos, Lima (MUSM) database from fishes sampled in Loreto department.

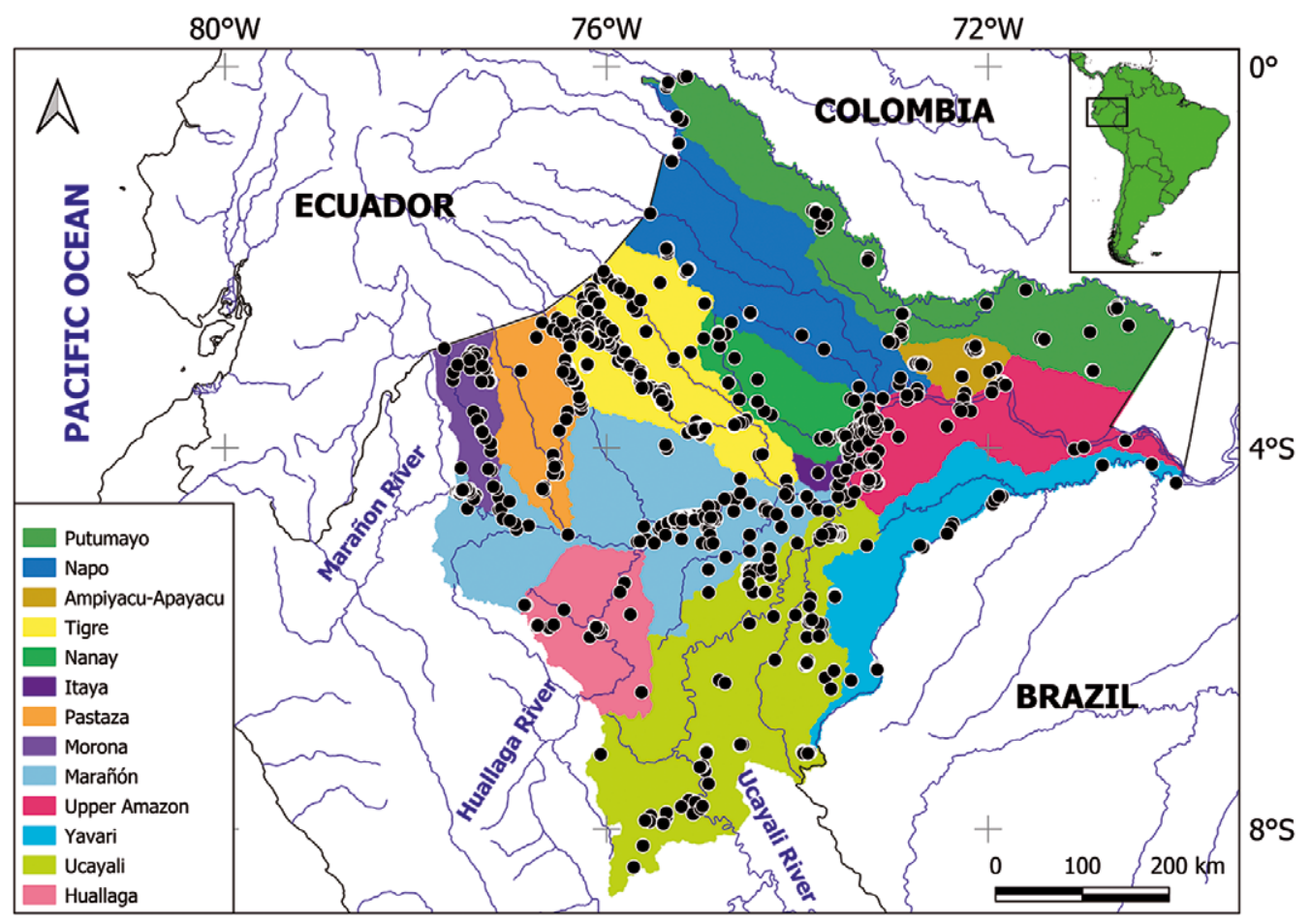

Figure 1. Loreto department showing main tributaries of the Amazon basin, sampling localities (black dots) taken from available databases 
The databases formed belongs to scientific collection, namely Academy of Natural Science of Philadelphia, Philadelphia (ANSP), California Academy of Sciences, San Francisco (CAS), Field Museum of Natural History, Chicago (FMNH), Museu de Ciências e Tecnologia da Pontifícia Universidade Católica do Rio Grande do Sul, Porto Alegre (MCP), Muséum national d'Histoire naturelle, Paris (MNHN), Museum of Comparative Zoology, Harvard University, Cambridge (MCZ), Museo de Historia Natural, Universidad Nacional Mayor de San Marcos, Lima (MUSM), Museu de Zoologia da Universidade de São Paulo, São Paulo (MZUSP), University of Florida, Florida Museum of Natural History, Gainesville (UF), University of Michigan Museum of Zoology, Ann Arbor (UMMZ), Museu de Zoologia da Universidade Estadual de Campinas "Adão José Cardoso", Campinas (ZUEC). Doubtful information, like no coordinates localities or unlikely coordinates, were discarded. Additionally, information was also compiled from available literature including species descriptions, taxonomic revision, and fish inventories and checklist (Appendix 1). This compilation covers 262 years of ichthyological information (Fig. 2).

The taxonomic nomenclature for order and families follows Betancur et al. (2017); valid names were confirmed following Eschmeyer Catalog of Fishes (Fricke et al. 2021). The use of aff. and $c f$. were avoided to try to get a precise number of species; in the same way, the use of "sp." was avoided except by few genera with no more species to represent. Nonnative species recorded from the natural environment in the Loreto department, with or without vouchers in fish collections were considered in a separate list and commented on in the discussion. Commercial species were taken from available information (García-Davila et al. 2018).

The conservation status of each species was taken from the last assessment following the IUCN criteria in 2014 available in https://www.iucnredlist.org/.

\section{Results}

Taxonomic composition. - Of the total information analysed, 21527 batches deposited in 10 scientific collections were registered. This annotated checklist reveals that the ichthyofauna in Loreto is composed of 873 valid species (Appendix 2), which included 38 new species described in the last eight years (Ortega et al. 2012) and taxonomic changes like transfers, synonyms, and distribution range extensions.

The species are distributed in 15 orders, 50 families and 331 genera (Table 2). Most of the ichthyofauna belongs to Otophysi (Cypriniformes, Characiformes, Silurformes, and Gymnotiformes) representing 86.0\% (750 species), with Characiformes being the most diverse order (372, species, $42.6 \%$ ), followed by Siluriformes (304, species, 34.8\%), and Gymnotiformes (75, species, 8.6\%); and with addition of Cichliformes (65, species, $7.4 \%$ ). The remaining 11 orders were represented by 57 species (6.5\%) (Fig. 3A).

Table 2. Number of family, genera, and species for each order of fishes registered in Loreto.

\begin{tabular}{lccc}
\hline Order & Family & Genera & Species \\
\hline Myliobatiformes & 1 & 3 & 5 \\
Lepidosireniformes & 1 & 1 & 1 \\
Osteoglossiformes & 2 & 2 & 2 \\
Clupeiformes & 2 & 7 & 15 \\
Characiformes & 19 & 122 & 372 \\
Gymnotiformes & 5 & 25 & 75 \\
Siluriformes & 11 & 133 & 304 \\
Batrachoidiformes & 1 & 1 & 1 \\
Cyprinodontiformes & 1 & 3 & 11 \\
Beloniformes & 1 & 3 & 6 \\
Synbranchiformes & 1 & 1 & 3 \\
Perciformes & 2 & 4 & 8 \\
Cichliformes & 1 & 22 & 64 \\
Carangiformes & 1 & 3 & 5 \\
Tetraodontiformes & 1 & 1 & 1 \\
Total & $\mathbf{5 0}$ & $\mathbf{3 3 1}$ & $\mathbf{8 7 3}$ \\
\hline
\end{tabular}

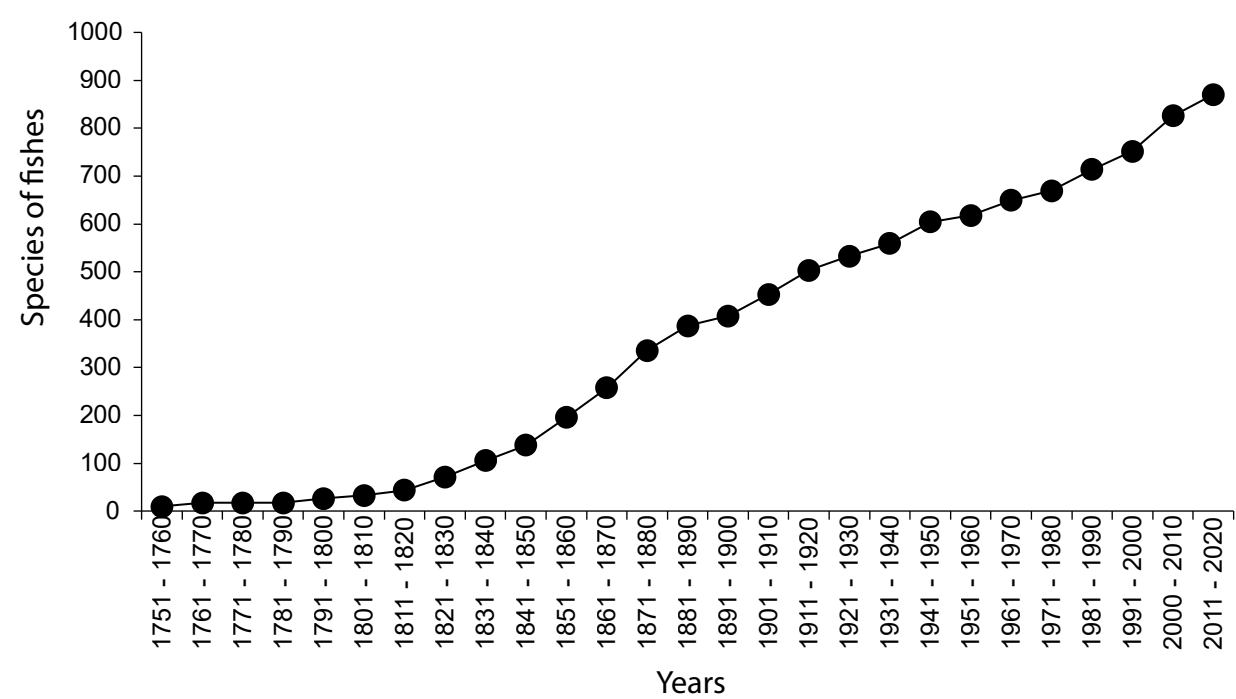

Figure 2. Cumulative curve of fish species described from Loreto department between 1758 - 2020, based on bibliographic information. 
In terms of family richness, Characidae is the richest with 178 species $(20.4 \%)$ followed by Loricariidae with 89 species (10.2\%), Cichlidae with 64 species $(7.3 \%)$, Pimelodidae with 41 species (4.7\%), Callichthyidae and Doradidae with 40 each (4.6\%) (Fig. 3B).

The most species-rich genera are found in Characidae; among them are Creagrutus, Hemigrammus, Hyphes- sobrycon, Moenkhausia. Among Loricariidae Hypostomus with 9 species, also Corydoras concentrated the most species in Callichthyidae with 33 of 40 species. In the same way, Apistogramma and Crenicichla together sum half of Cichlidae with 31 of 66 species. In Gymnotiformes, Brachyhypopomus and Gymnotus are represented by 21 species combined (Fig. 3C).

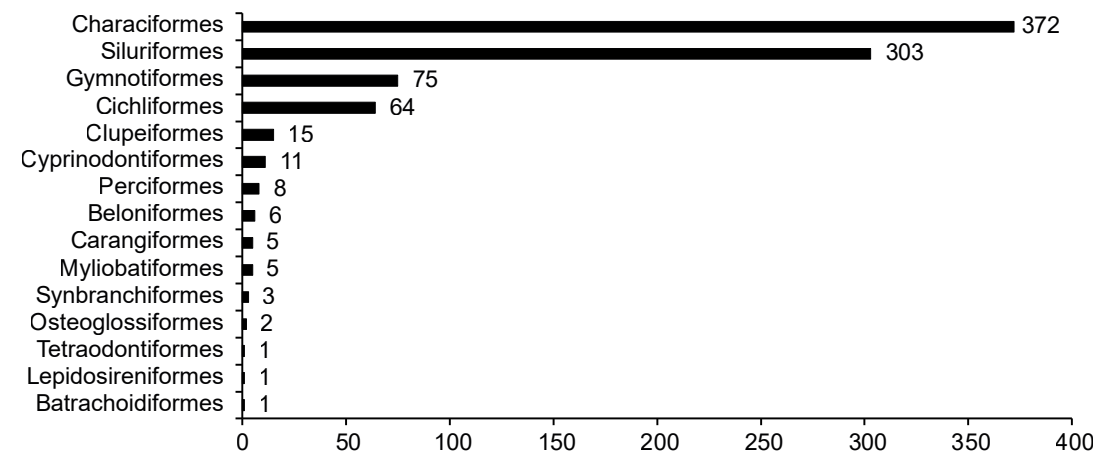

(A)

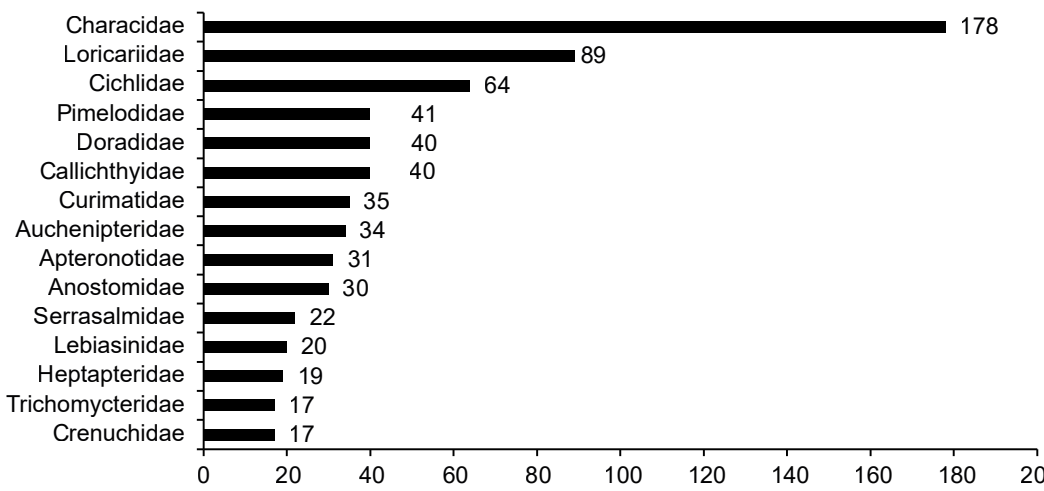

(B)

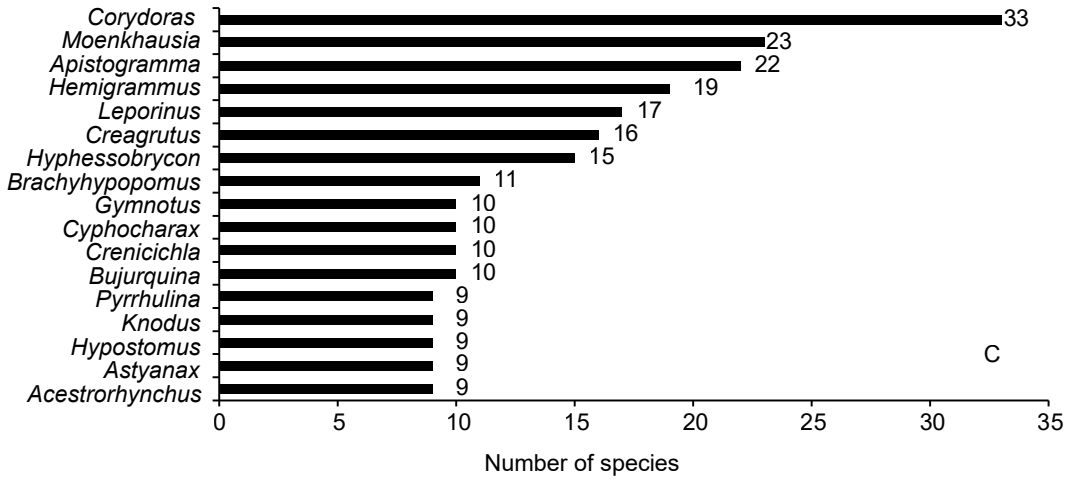

(C)

Figure 3. Richest taxa of fishes in number of species. A, orders; B, families; C, genera.

New species records. - New registers were added compared to the last list due recent taxonomic revisions, as Copella nattereri (Steindachner 1876), Astyanax symmetricus Eigenmann 1908, Jupiaba anterior (Eigenmann 1908), Knodus septentrionalis Géry 1972, Moenkhausia intermedia Eigenmann 1908, Trachelyopterus porosus (Eigenmann \& Eigenmann 1888), Tridensimilis brevis (Eigenmann \& Eigenmann 1889), Hypoptopoma brevirostratum Aquino \& Schaefer 2010.

Others registers omitted in the last lists were added as, Pellona altamazonica Cope 1872, Pyrrhulina melanos- tomus (Cope 1870), Mylossoma albiscopum (Cope 1872), Knodus borki Zarske 2008, Spinipterus acsi Akama \& Ferraris 2011, Aphanotorulus phrixosoma (Fowler 1940), Limatulichthys petleyi (Fowler 1940), Moema hellneri Costa 2003, Moema schleseri Costa 2003, Apistogramma amoena (Cope 1872).

Species with restricted distribution. - A total of 41 species (4.7\%) has restricted distribution for Loreto. Most of them are cichlids, belonging to Apistogramma, followed by the rivulids: Moema and Anablepsoides (Fig. 4, Appendix 2). 


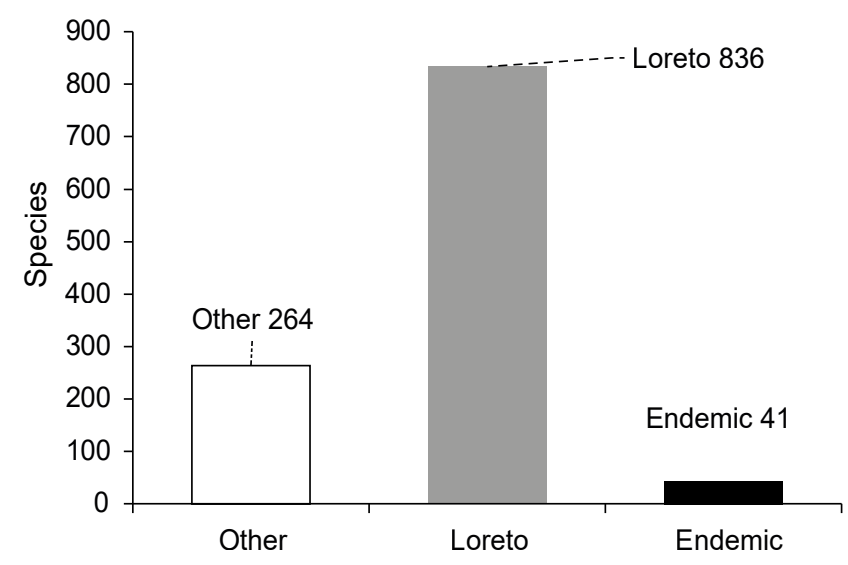

Figure 4. Freshwater fish species in Peru. Species distributed in other departments (white); species distributed in Loreto (gray) and species endemic from Loreto (black).

Commercially important species. - Large species that can surpass $1 \mathrm{~m}$ of standard length (SL), includes Arapaimidae, Osteoglossidae and mainly Pimelodidae (Brachyplatystoma, Pseudoplatystoma, Zungaro) which are known as migratory species. Some medium bodysize species up to $30 \mathrm{~cm}$ belongs to Anostomidae (Leporinus, Megaleporinus), Auchenipteridae (Auchenipterus, Tetranematichthys), Bryconidae (Brycon, Salminus), Curimatidae (Potamorhina), Cynodontidae (Hydrolycus, Rhaphiodon), Loricariidae (Panaque, Pterygoplichthys), etc. Most of the communities harbor small species; that is, individuals with SL up to $10 \mathrm{~cm}$, represented by 366 species (41\%). Those species belong to Characidae (Bryconamericus, Moenkhausia), Iguanodectidae (Bryconops), Heptapteridae (Mastiglanis), Loricariidae (Aphanotorulus), Gymnotidae (Gymnotus), etc. Also, species up to $26 \mathrm{~mm}$ SL known as miniature species are present in this list, represented in Engraulidae (Amazonsprattus scintilla), Characidae (Axelrodia stigmatias, Priocharax pygmaeus, Tyttobrycon hamatus, Xenurobrycon heterodon), Crenuchidae (Odontocharacidium aphanes), Callichthyidae (Corydoras pygmaeus), Doradidae (Physopyxis ananas), Pseudopimelodidae (Microglanis zonatus), Trichomycteridae (Tridentopsis pearsoni), etc.

In terms of commercial importance, small and medium species are used for aquarists (Apistogramma, Corydoras, Hemigrammus, etc.); medium and large-sized species are for human consumption (Pseudoplatystoma, Prochilodus, Potamorrhina, etc.) (Appendix 2).

Non-native species. - Exotic species are reported. Coptodon rendalli and Oreochromis niloticus (Tilapia), the livebearers Poecilia and Gambusia affinis and Trichopodus trichopterus are represented in collections (Table 3).

Threatened species. - Currently, a total of 217 species $(24.9 \%)$ are categorized following the IUCN criteria (Appendix 2). Only six species (0.7\%) are considered threatened species ("Critical Endangered" (CR), "Endangered" (EN) and "Vulnerable" (VU)). Additionally, two species were considered "Near Threatened" (NT) and 36 species as "Data Deficient" (DD). Finally, 173 species are considered as "Least Concern" (LC).
Table 3. Non-native species introduced in Loreto.

\begin{tabular}{lll}
\hline Order / Family & Species & IUCN \\
\hline $\begin{array}{c}\text { Cypriniformes } \\
\text { Cyprininae } \\
\text { Danionidae }\end{array}$ & $\begin{array}{l}\text { Cyprinus carpio Linnaeus 1758 } \\
\text { Danio rerio (Hamilton 1822) }\end{array}$ & VU \\
$\begin{array}{c}\text { Cyprinodontiformes } \\
\text { Poeciliidae }\end{array}$ & $\begin{array}{l}\text { Gambusia affinis (Baird \& Girard 1853) } \\
\text { Poecilia latipinna (Lesueur 1821) }\end{array}$ & LC \\
& $\begin{array}{l}\text { Poecilia reticulata Peters 1859 } \\
\text { Cichliformes }\end{array}$ & \\
Cichlidae & Coptodon rendalli (Boulenger 1897) & LC \\
& Oreochromis niloticus (Linnaeus 1758) & LC \\
Anabantiformes & & LC \\
Osphronemidae & Trichopodus trichopterus (Pallas 1770) & LC \\
\hline
\end{tabular}

\section{Discussion}

Taxonomic composition. - The diversity of fishes in Loreto is high, corresponding to $76.4 \%$ (873 spp.) of species known to occur in Peru (1141 spp; MINAM 2019). Fifteen years ago, there were 597 recorded species (CONAM 2005), and in the last checklist 724 species were reported. This represents an increase of $20 \%$. This value is incredibly high; over $76.4 \%$ of the species are recorded for only $28.7 \%\left(368.851 \mathrm{~km}^{2}\right)$ of the Peruvian territory (1 $285000 \mathrm{~km}^{2}$ ). Compared to terrestrial vertebrates (Pitman et al 2013), fishes of Loreto have the highest percentage of IUCN species (25.1\% vs. $19 \%$ or less) and the highest percentage of the total species reported for Peru (76.4\% vs. $49.2 \%$ or less). Furthermore, fishes of Loreto have the second highest number of endemics species (4.9\%) following amphibia (5.6\%). This clearly shows the relevance of fish diversity in this region.

As in other lists or inventories in the Neotropical region, the most species-rich orders belong to Otophysi representing around $80 \%$ of species in total. In the same way, the most species-rich families follow the typical pattern for Amazonia fish composition: dominated for Characidae, Loricariidae, Cichlidae, Pimelodidae, Doradidae and Callichthyidae (Beltrão et al. 2019, Dagosta \& de Pinna 2019).

New species records. - Although the list provided here considers species-level names only, there were some genera that could represent new species (Scorpiodoras, Phenacorhamdia, Astroblepus), even some of them are in the description process. Also, the species Rhamdia cf. quelen and Trichomycterus cf. rivulatus present some doubts related with its taxonomic status and need to be reviewed in detail. Besides that, Astroblepus, Chaetostoma and Trichomycterus are genera with typical distribution along an elevational gradient in the Andes, collected in the lowest slopes of Andes belonging to Loreto. Overall, those genera are diverse and endemic for sub basins; they can represent potential new species.

The Field Museum Rapid Biological Inventories have contributed to the knowledge of fishes from Loreto due to most of them being carried out in places with difficult access (Table 1). A total of 45 potential new species is 
estimated from 15 inventories in Loreto. Of these, only 11\% have been described (Panaque schaeferi, Hypostomus fonchii, Corydoras ortegai, Hemibrycon divisoriensis, Mastiglanis yaguas and Cetopsorhamdia hidalgoi). This demonstrates there still is more effort to make in taxonomic and systematic studies.

Species with restricted distribution. - Four point seven percent of the species (4.7\%, 41 spp. of 873 spp.) have restricted distribution in Loreto (Appendix 2). Most available information of fish endemicity is expressed by basin, for instance, Marañón and Ucayali basins have high levels of endemism with $25 \%$ and $16 \%$ respectively (Dagosta \& de Pinna 2019). For this reason, our results are not comparable with previous studies because they are regional. However, we believe that the lower portion of each basin can contribute to the richness of Piedmont species which are different from lowland species.

Commercially important species. - Fishing is one of the main economic activities in Peruvian Amazon; 79 species are part of fisheries resources (García-Dávila et al. 2018), representing $9 \%$ of the total species from Loreto. Thus, most species are not used for fisheries or any commercial purposes (91\%). As was mentioned before, there is an enormous diversity of fishes in terms of size, body shape, colour pattern, etc., which are of interest of researchers with different focuses (systematic, taxonomy, ecology, genetic, phylogeny, etc.). However, the Peruvian government considers all freshwater fishes as fisheries or hydro-biological resources, which are under the supervision of the Ministry of Production, rather than being considered as fauna under the management of the Ministry of the Environment. This misconception of fisheries resources is problematic for research (i.e.: permission for collecting fishes, permission for exportation, of individuals as well DNA analysis) and conservation (IUCN categorization). Several countries in the Neotropical region manage freshwater fishes as fauna that allow them to make research about checklists by basin or departments, conservation status and red list (IUCN), scientific expeditions, etc. This kind of management politics can improve the knowledge and conservation of freshwater fish diversity in Peru.

Finally, the present study can contribute to the management of fisheries to get precise catchment for species as well as for fauna since it contains an update of the fish list for Loreto.

Non-native species. - Exotic fishes have been introduced into natural habitats in Peru for different purposes since 1930s. For example, the tilapia (Coptodon rendalli) was introduced repeatedly into coastal and central Amazon basin to increase food availability to local community. Livebearers (Poecilia latipinna and Gambusia affinis) were introduced to control malaria insects during the 1950s (Ortega et al. 2007). Additionally, other introductions, such as Cyprinus carpio, Oreochromis niloticus and Poecilia reticulata also were registered for lower Huallaga River (Ortega et al. 2007).

Trichopodus trichopterus can be found around Iqui- tos streams and recently was collected next to Quistocoha by H. Sánchez (Pers. Comm. 2019). Many decades ago (1980-1990), there was some ornamental activity around this group from Moronacocha, a lagoon very close to the city and connected to Nanay River. In addition, Danio rerio (Cypriniformes) known as zebra fish, were registered in a consulting work in a lentic body of water between Nauta and Iquitos (Urku \& Brirell 2016). The introduction of exotic species into natural habitats caused several problems such as predation, competition for resources and for niches. The species reported herein are adapted to warm water, and that facilitated their dispersion (Ortega et al. 2012, Ortega et al. 2007). Some of these species do not have vouchers in collections but as mentioned before, they are already in natural habitats (Table 3) and it is necessary to take some control actions to minimize the effects.

Incidental presence of shark has been recorded in Iquitos. Carcharhinus leucas was registered the first time in 1952 by Myers who identified a single specimen by a photo (Gausmann 2018, unpublished report). Although the bull shark has been registered in several rivers in different continents, the farthest penetration and longest movement into freshwater is provided for the Amazon River, more than $5000 \mathrm{~km}$ away from the mouth of the river at the coastline of the Atlantic Ocean. The distribution of this species is limited by water temperature, not only in coastal, but even in freshwater systems (Castro 2010).

Gaps of information. - Even though, almost all the sub-basins of the department have been studied, there still are some gaps to fill. For instance, the middle Napo River, some tributaries of Marañón River, Yavarí River, and some tributaries between Huallaga River and Ucayali River (Fig. 1). These areas should be prioritized for ichthyological surveys.

Conservation. - Several threats have been identified in Loreto derived from economic activities such as deforestation, illegal logging, artisanal fluvial gold mining, pollution, road constructions, hydroelectric dam and $\mathrm{Hi}-$ drovia projects. All of these threats have affected the environment in the past but might especially affect aquatic habitats and their fish fauna in the future.

Although the time for the collections were limited, the information obtained in biological inventories was valuable. Not only to know the diversity in those places at the time, but also to know the conservation state of the area and the local communities that live there. It is important to mention that the most remarkable thing of those inventories was that they were taken as a baseline to propose national protected areas (NPA) where $53 \%$ of them led to the creation of an NPA in some category (Pitman et al. 2021) (Table 1).

It is worth mentioning that the last meeting of categorization of Peruvian fishes was focused on Andean fishes (IUCN, 2014). "Near threatened" and "Data deficient" indicate lack of information about distribution, natural history, size or density population and ecology of those species (Bertaco et al. 2016), hence encourag- 
ing more studies to be made on those species. Besides that, species considered as "Least concern" can give an appearance of the stability of the conservation status of those species; however, they need to be updated due new threats, which can appear. Overall, more efforts need to be made to complete the assessment of Peruvian fish species and particularly from the Loreto department.

\section{Literature cited}

Abell R, Thieme ML, Revenga C, Bryer M, Kottelat M, Bogutskaya N, Coad B, Mandrak N, Balderas SC, Bussing W, Stiassny ML. 2008. Freshwater ecoregions of the world: a new map of biogeographic units for freshwater biodiversity conservation. BioScience 58(5):403-414. https://doi.org/10.1641/B580507

Angulo A, Garita-Alvarado CA, Bussing WA, López MI. 2013. Annotated checklist of the freshwater fishes of continental and insular Costa Rica: additions and nomenclatural revisions. Check List 9(5):987-1019. https:// doi.org/10.15560/9.5.987.

Alverson WS, Rodríguez LO, Moskovits DK. 2001. Rapid biological inventories Perú biabo cordillera Azul. The Field Museum. 228pp. Barriga R. 2012. Lista de peces de agua dulce e intermareales del Ecuador. Revista Politecnica 2012 30(3):83-119. http://bibdigital.epn. edu.ec/handle/15000/5058.

Armas Loarte M, Ricce R, Valenzuela S, and Ortega H. 2021. Ichthyological Diversity of the Mayapo Stream, Peruvian Amazon . Revista Peruana de Biología 28 (1):e17751. https://doi.org/10.15381/rpb.v28i1.17751.

Beltrão H, Zuanon J, Ferreira E. 2019. Checklist of the ichthyofauna of the Rio Negro basin in the Brazilian Amazon. ZooKeys 881:53-89. https://doi.org/10.3897/ zookeys.881.32055.

Bertaco VA, Ferrer J, Carvalho FR, Malabarba LR. 2016. Inventory of the freshwater fishes from a densely collected area in South America-a case study of the current knowledge of Neotropical fish diversity. Zootaxa 4138(3):401-440. https://doi.org/10.11646/ zootaxa.4138.3.1.

Betancur R, Wiley EO, Arratia G, Acero A, Bailly N, Miya M, Lecointre G, Orti G. 2017. Phylogenetic classification of bony fishes. BMC evolutionary biology 17:162pp. https://doi.org/10.1186/s12862-017-0958-3.

Carvalho TP, Tang SJ, Fredieu JI, Quispe R, Corahua I, Ortega H, Albert JS. 2009. Fishes from the upper Yuruá river, Amazon basin, Peru. Check list 5(3):673-691. https:// doi.org/10.15560/5.3.673.

Carvalho TP, Flores JA, Espino J, Trevejo G, Ortega H, Jerep FC, dos Reis RE, Albert J. 2012. Fishes from the Las Piedras River, Madre de Dios basin, Peruvian Amazon. Check List 8(5):973-1019. https://doi. org/10.15560/8.5.973.

Castro JI. 2010. The sharks of north America. Oxford University Press. 611pp.

CONAM (Consejo Nacional del Ambiente). 2005. Indicadores Ambientales, Loreto. Series Indicadores Ambientales 7. Consejo Nacional del Ambiente:Lima, 60pp. https://sinia.minam.gob.pe/documentos/serie-indicadores-no-07-indicadores-ambientales-region-loreto

Corahua I, Aldea-Guevara MI, Hidalgo MH. 2015. Peces, in: N. Pitman, C. Vriesendorp, L. Rivera Chávez, T. Wachter, D. Alvira Reyes, Á. del Campo, G. Gagliardi-Urrutia, D. Rivera González, L. Trevejo, D. Rivera González, S.
Heilpern (Eds.), Perú: Tapiche-Blanco. Rapid Biological and Social Inventories Report 27. The Field Museum, Chicago, pp. 109-117, 290-297. http://fm2.fieldmuseum.org/rbi/pdfs/peru27/RI27 Fishes Corahua 2015.pdf

Correa E, Ortega H. 2010. Diversidad y variación estacional de peces en la cuenca baja del río Nanay, Perú. Revista peruana de biología 17(1):37-42. https://doi. org/10.15381/rpb.v17i1.48

Dagosta FC, de Pinna MC. 2018. A history of the biogeography of Amazonian fishes. Neotropical Ichthyology, 16(3): e180023. https://doi.org/10.1590/1982-022420180023.

Dagosta FC, De Pinna M. 2019. The fishes of the Amazon: distribution and biogeographical patterns, with a comprehensive list of species. Bulletin of the American Museum of Natural History, 2019(431): 1-163. https://doi. org/10.1206/0003-0090.431.1.1

DoNascimiento C, Herrera-Collazos EE, Herrera GA, Ortega-Lara A, Villa-Navarro FA, Oviedo JSU, Maldonado-Ocampo JA. 2017. Checklist of the freshwater fishes of Colombia: a Darwin Core alternative to the updating problem. ZooKeys 708:25-138. https://doi. org/10.3897/zookeys.708.13897

Dos Reis RB, Frota A, Depra GDC, Ota RR, Da Graca WJ. 2020. Freshwater fishes from Paraná State, Brazil: an annotated list, with comments on biogeographic patterns, threats, and future perspectives. Zootaxa, 4868(4):451-494. https://doi.org/10.11646/ zootaxa.4868.4.1

Faustino-Fuster DR, Patarroyo Báez JJ, de Souza LS. 2021. Peces/ Fishes. Pp. 138-145, 386- 392 and 564-573 in Jarrett, C. C., M. E. Thompson, N. Pitman, C. F. Vriesendorp, D. Alvira Reyes, A. A. Lemos, F. Carrasco-Rueda, W. Matapi Yucuna, A. Salazar Molano, A. R. Sáenz Rodríguez, F. Ferreyra, Á. del Campo, M. Morales, A. Alfonso, T. Torres Tuesta, M. C. Herrera Vargas, C. García Ortega, V. Cardona Uribe, N. Kotlinski, D. K. Moskovits, L. S. de Souza and D. F. Stotz, (Eds.), Colombia, Perú: Bajo Putumayo-Yaguas-Cotuhé. Rapid Biological and Social Inventories Report 31. Field Museum, Chicago.

Fricke R, Eschmeyer WN, Van der Laan R. 2021. Catalog of fishes: genera, species, references. California Academy of Sciences, San Francisco, CA, USA https://researcharchive.calacademy.org/research/ichthyology/catalog/ fishcatmain.asp

García-Dávila C, Sánchez H, Flores M, Mejia J, Angulo C, Castro-Ruiz D, Estivals G, García A, Vargas G, Nolorbe C, Núñez J, Mariac C, Duponchelle F, Renno J-F. 2018. Peces de consumo de la Amazonía peruana. Instituto de Investigaciones de la Amazonía Peruana (IIAP). Iquitos, Perú, 218 pp. http://repositorio.iiap.gob.pe/ handle/IIAP/368.

Gausmann P. 2018. Synopsis of global freshwater occurrences of the bull shark (Carcharhinus leucas Valenciennes 1839, Carcharhinidae) with comments on the geographical range. Unpublished report.

Hidalgo M, Aldea-Guevara MI. 2014. Peces, in: N. Pitman, C. Vriesendorp, D. Alvira, J.A. Markel, M. Johnston, E.R. Inzunza, A.L. Pizango, G.S. Valenzuela, P. Álvarez-Loayza, J. Homan, T. Wachter, A. del Campo, D.F. Stotz, S. Heilpern (Eds.), Perú: Cordillera Escalera-Loreto. Rapid Biological and Social Inventories Report 26. The Field Museum, Chicago, pp.119-127, 312-319. http://fm2.fieldmuseum.org/rbi/pdfs/peru26/ RI26-Fishes.pdf 
Hidalgo M, Maldonado-Ocampo J. 2016. Peces, in N. Pitman, A. Bravo, S. Claramunt, C. Vriesendorp, D. Alvira Reyes, A. Ravikumar, A. del Campo, D.F. Stotz, T. Wachter, S. Heilpern, B. Rodríguez Grández, A.R. Sáenz Rodríguez, R.C. Smith (Eds.), Perú: Medio Putumayo-Algodón. Rapid Biological and Social Inventories Report 28. The Field Museum, Chicago, pp. 109-119, 291-300. http://fm2.fieldmuseum.org/rbi/pdfs/peru28/ RI28\%20Fishes\%20Hidalgo\%20Maldonado-Ocampo\%202016.pdf

Hidalgo M, Olivera R. 2004. Peces, in: N. Pitman, R.C. Smith, C. Vriesendorp, D. Moskovits, R. Piana, G. Knell, T. Watcher (Eds.), Perú: Ampiyacu, Apayacu, Yaguas, Medio Putumayo. Rapid Biological Inventories Report 12. Chicago, Illinois: The Field Museum, pp. 62-67, 148-152. http://fm2.fieldmuseum.org/rbi/pdfs/peru12/ per12 narr esp.pdf

Hidalgo M, Ortega-Lara A. 2011. Peces, in: N. Pitman, C. Vriesendorp, D. Moskovits, R. von May, D. Alvira, T. Watcher, D.F. Stotz, A. Del Campo (Eds.), Perú: Yaguas-Cotuhé. Rapid Biological and Social Inventories Report 23. Chicago, IL: The Field Museum, pp.98-107, 221-230. http://fm2.fieldmuseum.org/rbi/pdfs/peru23/RI23 SPANISH v9.pdf

Hidalgo M, Pezzi J. 2006. Peces, In: C. Vriesendorp, T.S. Schulenberg, W.S. Alverson, D.K. Moskovits, M.J.I. Rojas (Eds), Perú: Sierra del Divisor: Rapid Biological Inventories Report 17. Chicago, Illinois: The Field Museum, pp. 73-83, 173-182. http://fm2.fieldmuseum.org/rbi/ temp/Sierra_del_Divisor_Spanish.pdf

Hidalgo M, Rivadeneira JF. 2008. Peces, in: W.S. Alverson, C. Vriesendorp, A. Del Campo, D.K. Moskovits, D.F. Stotz, M. García Donayre, L.A. Borbor (Eds.), Ecuador, Perú: Cuyabeno-Gueppi. Rapid Inventories Biological and Social Report 20. Chicago, IL: The Field Museum, pp 83-89, 209-215. http://fm2.fieldmuseum.org/rbi/ pdfs/gueppi_esp.pdf

Hidalgo M, Sipión I. 2010. Peces, in: M.P. Gilmore, C. Vriesendorp, W.S. Alverson, A. del Campo, R. von May, C.L. Wong, S.R. Ochoa (Eds.), Perú: Maijuna. Rapid Biological and Social Inventories Report 22. Chicago, IL: The Field Museum, pp 66-73, 183-190. http://fm2.fieldmuseum.org/rbi/pdfs/RI22_Spanish.pdf

Hidalgo M, Velásquez M. 2006. Peces, in: C. Vriesendorp, N. Pitman, M.J.I. Rojas, B.A. Pawlak, C.L. Rivera, M.L. Calixto, C.M. Vela, R.P. Fasabi (Eds.), Perú: Matsés: Rapid Biological Inventories Report 16. Chicago, Illinois: The Field Museum, pp 74-83,184-191. http://fm2.fieldmuseum.org/rbi/temp/Matses_Spanish.pdf

Hidalgo M, Willink PW. 2007. Peces, in: C. Vriesendorp, J.A. Álvarez, N. Barbagelata, W.S. Alverson, D. Moskovits (Eds.), Perú: Nanay-Mazán-Arabela. Rapid Biological Inventories Report 18. Chicago, IL: The Field Museum, pp 56-62, 125-130. http://fm2.fieldmuseum.org/ rbi/temp/NMA_Spanish.pdf

Jézéquel C, Tedesco PA, Bigorne R, Maldonado-Ocampo JA, Ortega $\mathrm{H}$, Hidalgo $\mathrm{M}$, et al. 2020. A database of freshwater fish species of the Amazon Basin. Scientific Data 7(96):1-9. https://doi.org/10.1038/s41597-0200436-4.

Jiménez P, Aguirre W, Laaz E, Navarrete R, Nugra F, Rebolledo E, Zárate E, Torres A, Valdiviezo J. 2015. Guía de peces para aguas continentales en la vertiente occidental del Ecuador. Pontificia Universidad Católica Del Ecuador Sede Esmeraldas, Esmeraldas. 415pp.

Koerber S, Litz TO. 2014. Check List of the Freshwater Fishes of Uruguay (CLOFFUY)-Update 1. Ichthyological Contri- butions of PecesCriollos 30:1-6.

Koerber S, Vera-Alcaraz HS, Reis RE. 2017. Checklist of the fishes of Paraguay (CLOFPY). Ichthyological Contributions of PecesCriollos 53:1-99.

Lasso CA, Machado-Allison A, Taphorn DC 2016. Fishes and aquatic habitats of the Orinoco River Basin: diversity and conservation. Journal of fish biology 89(1):174191. https://doi.org/10.1111/jfb.13010.

Le BaiL PY, Covain R, Jégu M, Fisch-Muller S, Vigouroux R, Keith P. 2012. Updated checklist of the freshwater and estuarine fishes of French Guiana. Cybium 36(1):293-319. https://doi.org/10.26028/cybium/2012-361-016.

Leite RN, Rogers DS. 2013. Revisiting Amazonian phylogeography: insights into diversification hypotheses and novel perspectives. Organisms Diversity \& Evolution 13(4):639-664. https://doi.org/10.1007/ s13127-013-0140-8.

Maldonado-Ocampo JA, Vari RP, Usma JS. 2008. Checklist of the freshwater fishes of Colombia. Biota Colombiana 9(2):143-237. http://revistas.humboldt.org.co/index. $\mathrm{php} / \mathrm{biota} /$ article/view/201/200

Maldonado-Ocampo J, Quispe R, Hidalgo M. 2013. Peces, in N. Pitman, E. Ruelas Inzunza, C. Vriesendorp, D.F. Stotz, T. Wachter, A. del Campo, D. Alvira, B. Rodríguez Grández, R.C. Smith, A.R. Sáenz Rodríguez, P. Soria Ruiz (Eds.), Perú: Ere-Campuya-Algodón. Rapid Biological and Social Inventories Report 25. Chicago, IL: The Field Museum, pp. 98-107, 243-251. http://fm2. fieldmuseum.org/rbi/pdfs/peru25/RI25_SPANISH_ PRINT.pdf

Matamoros WA, Schaefer JF, Kreiser BR. 2009. Annotated checklist of the freshwater fishes of continental and insular Honduras. Zootaxa 2307:1-38. https://doi. org/10.11646/zootaxa.2307.1.1.

MINAM (Ministerio del Ambiente). 2011. Evaluación hidrológica de las cuencas Amazónicas Peruanas. Ministerio del Ambiente:Lima. 33pp.

MINAM (Ministerio del Ambiente). 2019. Sexto informe nacional sobre Diversidad Biológica. La Biodiversidad en cifras. Ministerio del Ambiente:Lima. https://cdn. www.gob.pe/uploads/document/file/360831/La_Biodiversidad_en_Cifras_final.pdf

Mirande JM, Koerber S. 2015. Checklist of the freshwater fishes of Argentina (CLOFFAR). Ichthyological Contributions of Peces Criollos 36:1-68.

Mol JHA, Vari RP, Covain R, Willink PW, Fisch-Muller S. 2012. Annotated checklist of the freshwater fishes of Suriname. Cybium v. 36 (no. 1): 263-292. https://doi. org/10.26028/cybium/2012-361-015.

Ohara WM, Lima FCT, Salvador GN, Andrade MC. 2017. Peixes do rio Teles Pires: diversidade e guia de identificação. Gráfica Amazonas e Editora Ltda-EPP, Aparecida de Goiânia.

Ortega H, Vari RP. 1986. Annotated checklist of the freshwater fishes of Peru. Smithsonian Contributions to Zoology 437:1-25. https://doi.org/10.5479/si.00810282.437

Ortega H, Hidalgo M, Bértiz G. 2003. Los Peces del río Yavarí, in: N. Pitman, C. Vriesendorp, Moskovits D (Eds.), Yavari: Rapid Biological Inventories Report 11. Chicago, IL: The Field Museum, pp. 59-62, 220-243. http:// fm2.fieldmuseum.org/rbi/pdfs/peru11/per11_entire_esp.pdf

Ortega H, Mojica JI, Alonso JC, Hidalgo M. 2006. Listado de los peces de la cuenca del río Putumayo en su sector 
colombo-peruano. Biota Colombiana 7(1):95-111. http://revistas.humboldt.org.co/index.php/biota/issue/view/24/58.

Ortega H, Guerra H, Ramírez R. 2007. The Introduction of Nonnative Fishes into Freshwater Systems of Peru, in: Bert T.M. (Ed.), Ecological and Genetic Implications of Aquaculture Activities. Methods and Technologies in Fish Biology and Fisheries, vol 6. Springer, Dordrecht, pp.247-278. https://doi.org/10.1007/978-1-40206148-6_14

Ortega H, Hidalgo M, Trevejo G, Correa E, Cortijo AM, Meza V, Espino J. 2012. Lista anotada de los peces de aguas continentales del Perú: Estado actual del conocimiento, distribución, usos y aspectos de conservación. Ministerio del Ambiente, Dirección General de Diversidad Biológica, Museo de Historia Natural, UNMSM, pp. 56. http://bibliotecavirtual.minam.gob.pe/biam/handle/ $\underline{\operatorname{minam} / 873}$

Palacios V, Ortega H. 2008. Diversidad ictiológica del Río Inambari, Madre de Dios, Perú Revista Peruana de Biología 15(2): 59-64. https://doi.org/10.15381/rpb. $\mathrm{v} 15 \mathrm{i} 2.1723$

Pitman N, Inzunza ER, Alvira D, Vriesendorp C, Moskovits DK, del Campo A, Wachter T, Stotz DF, Sesén SN, Cerrón ET, Smith RC. 2012. Perú: Cerros de Kampankis. Rapid Biological and Social Inventories Report 24. Chicago, IL: The Field Museum, pp 452. http://fm2.fieldmuseum. org/rbi/pdfs/peru24/RI24_SPANISH.pdf

Pitman N, Vriesendorp C, Alvira D, Markel JA, Johnston M, Inzunza ER, Pizango AL, Valenzuela GS, Álvarez-Loayza P, Homan J, Wachter T. 2014. Peru: Cordillera Escalera-Loreto. Rapid Biological and Social Inventories Report 26. Chicago, IL: The Field Museum, pp. 541. http://fm2.fieldmuseum.org/rbi/pdfs/peru26/RI26Full-report.pdf

Pitman N, Vriesendorp CF, Reyes DA, Moskovits DK, Kotlinski N, Smith RC, et al. 2021. Applied science facilitates the large-scale expansion of protected areas in an Amazonian hot spot. Sci Adv. 2021 Jul 30;7(31):eabe2998. https://doi.org/10.1126/sciadv.abe2998

Pitman N, Gagliardi Urrutia G,Jenkins C. 2013. La Biodiversidad de Loreto, Perú: El conocimiento actual de plantas y vertebrados terrestres. Center for International Environmental Law (CIEL), pp. 40.

Quezada MG, Hidalgo M, Tarazona J, Ortega H. 2017. Ictiofauna de la cuenca del río Aguaytía, Ucayali, Perú. Revista Peruana de Biología, 24(4), 331-342. http://dx.doi. org/10.15381/rpb.v24i4.14061.

Quispe R, Hidalgo M. 2012. Peces, in: N Pitman, Inzunza ER, Alvira D, Vriesendorp C, Moskovits DK, del Campo A, Wachter T, Stotz DF, Sesén SN, Tuesta E, Smith RC (Eds.). Perú: Cerros de Kampankis. Rapid Biological and Social Inventories Report 24. Chicago, IL: The Field Museum, pp. 96-106, 250-260. http://fm2.fieldmuseum.org/rbi/pdfs/peru24/RI24_SPANISH.pdf

de Rham P, Hidalgo M, Ortega H. 2001. Los Peces del Biabo-Cordillera Azul, en: Alverson, W.S., Rodríguez, L.O., \& Moskovits, D. (eds.). Perú: Biabo Cordillera Azul", Rapid Biological Inventories Report 2. Chicago, IL: The Field Museum, pp. 64-69, 137-141. http://fm2.fieldmuseum.org/rbi/pdfs/peru02/cdAzulEntireEsp.pdf

Reis RE, Albert JS, Di Dario F, Mincarone MM, Petry P, Rocha LA. 2016. Fish biodiversity and conservation in South America. Journal of fish biology 89(1):12-47. https:// doi.org/10.1111/jfb.13016.

Rengifo B. 2007. Diversidad de peces en la cuenca del Alto
Yuruá (Ucayali, Perú). Revista Peruana de Biología 13(3):195-202. https://doi.org/10.15381/rpb. v13i3.2337

Sarmiento J, Bigorne R, Carvajal-Vallejos FM, Maldonado M, Leciak E, Oberdorff T. 2014. Peces de Bolivia / Bolivian fishes. IRD-BioFresh (EU), Plural editores, Bolivia, 211pp.

Silva AT, Chagas RJ, Santos ACDA, Zanata AM, Rodrigues BK, Polaz CNM, Alves CBM, Vieira CS, Souza FB, Vieira F, Sampaio FAC. 2020. Freshwater fishes of the Bahia State, Northeastern Brazil. Biota Neotropica, 20(4): e20200969, 2020. https://doi.org/10.1590/16760611-bn-2020-0969.

Urku \& Brirell (Asociación Urku Estudios amazónicos - Brire11). 2016. Servicio de consultoria para la Prospección, distribución y análisis socio-económico de los peces ornamentales en las regiones de Loreto y Ucayali. Tercer entregable, contrato $\mathrm{N}^{\circ}$ 039-2016-MINAM-OGA. https://bioseguridad.minam.gob.pe/wp-content/uploads/2017/02/peces_orn_loreto_ucayali.pdf

Van der Sleen P, Albert, JS. 2017. Field Guide to the Fishes of the Amazon, Orinoco and Guianas. Princeton University Press.

Venticinque EM, Forsberg BR, Barthem RB, Petry P, Hess LL, Mercado A, Cañas C, Montoya M, Durigan CC, Goulding M. 2016. An explicit GIS-based river basin framework for aquatic ecosystem conservation in the Amazon. Earth System Science Data 8(2): 651-661. https://repositorio.inpa.gov.br/handle/1/15789.

\section{Agradecimientos / Acknowledgments:}

We are grateful to all researchers and ichthyologists who have contributed increase knowledge about the ichthyofauna in Loreto over the time. This work has been possible due to database available from different institutions/collections, Academy of Natural Science of Philadelphia, Philadelphia (ANSP), California Academy of Sciences, San Francisco (CAS), Field Museum of Natural History, Chicago (FMNH), Museu de Ciências e Tecnologia da Pontifícia Universidade Católica do Rio Grande do Sul, Porto Alegre (MCP), Muséum national d'Histoire naturelle, Paris (MNHN), Museum of Comparative Zoology, Harvard University, Cambridge (MCZ), Museo de Historia Natural, Universidad Nacional Mayor de San Marcos, Lima (MUSM), Museu de Zoologia da Universidade de São Paulo, São Paulo (MZUSP), University of Florida, Florida Museum of Natural History, Gainesville (UF), University of Michigan Museum of Zoology, Ann Arbor (UMMZ), Museu de Zoologia da Universidade Estadual de Campinas "Adão José Cardoso", Campinas (ZUEC).

Conflicto de intereses / Competing interests:

The authors declare no conflict of interest.

\section{Rol de los autores / Authors Roles:}

VMV, DRFF, JC, MH: conceptualization, investigation, methodology, data curation. VMV, DRFF, JC: formal analysis. VMV: writing original draft. VMV, DFF, JC, MH, HO: writing, review and editing.

Fuentes de financiamiento / Funding:

Wildlife Conservation Society (WCS).

Aspectos éticos / legales; Ethics / legals:

Authors declare that they did not violate or omit ethical or legal norms in this research. 
Appendix 1. Literature sources for distributional data on Amazonian fishes from Loreto, Peru.

Carvalho MRD \& Ragno MP. 2011. An unusual, dwarf new species of Neotropical freshwater stingray, Plesiotrygon nana sp. nov., from the upper and mid Amazon basin: the second species of Plesiotrygon (Chondrichthyes: Potamotrygonidae). Papéis Avulsos de Zoologia, 51(7), 101138.

Carvalho MD, Sabaj-Perez MH \& Lovejoy NR. 2011. Potamotrygon tigrina, a new species of freshwater stingray from the upper Amazon basin, closely related to Potamotrygon schroederi Fernandez-Yépez, 1958 (Chondrichthyes: Potamotrygonidae). Zootaxa, 2827(1), 1-30.

Loeb MV, Varella HR \& Menezes NA. 2018. A new species of Anchoviella (Clupeiformes: Engraulidae) from the western Amazon River in Peru, with comments on congeners in the Peruvian Amazon River. Journal of fish biology, 92(6), 1720-1730.

Loeb MV. 2012. A new species of Anchoviella Fowler, 1911 (Clupeiformes: Engraulidae) from the Amazon basin, Brazil. Neotropical Ichthyology, 10(1), 13-18.

Menezes NA \& de Pinna MCC. 2000. A new species of Pristigaster, with comments on the genus and redescription of P-cayana (Teleostei: Clupeomorpha: Pristigasteridae). Proceedings of the Biological Society of Washington, 113(1), 238-248.

Pellegrin J. 1909. Characinidés américains nouveaux de la collection du Muséum d'Histoire naturelle.

Vari RP. 1992. Systematics of the neotropical characiform genus Cyphocharax Fowler (Pisces: Ostariophysi). Smithsonian Contributions to Zoology.

Vari RP. 1984. Systematics of the neotropical characiform genus Potamorhina (Pisces, Characiformes). Smithsonian Contributions to Zoology.

Vari RP. 1989. Systematics of the Neotropical characiform genus Pseudocurimata Fernández-Yépez (Pisces: Ostariophysi). Smithsonian Contributions to Zoology.

Vari RP. 1991. Systematics of the neotropical characiform genus Steindachnerina Fowler (Pisces: Ostariophysi). Smithsonian Contributions to Zoology.

Vari RP \& Vari AW. 1989. Systematics of the Steindachnerina hypostoma complex (Pisces, Ostariphysi, Curimatidae) with the description of three new species. Proceedings of the Biological Society of Washington, 102(2), 468-482.

Eigenmann CH \& Smith-Eigenmann R. 1889. Preliminary notes on South American nematognathi.

Günther A. 1864. Catalogue of the fishes in the British Museum. Catalogue of the Physostomi, containing the families Siluridae, Characinidae, Haplochitonidae, Sternoptychidae, Scopelidae, Stomiatidae in the collection of the British Museum. Catalogue of the fishes in the British Museum, 5, $\mathrm{i}-\mathrm{xxii+}$

Dos Santos GM \& Zuanon J. 2008. Leporinus amazonicus, a new anostomid species from the Amazon lowlands, Brazil (Osteichthyes: Characiformes). Zootaxa, 1815(1), 35-42.

Fowler HW. 1914. Fishes from the Rupununi River, British Guiana. Proceedings of the Academy of Natural Sciences of Philadelphia, 229-284.

Eigenmann CH \& Henn AW. 1916. Description of three new species of characid fishes. New Era Print. Company.

Birindelli JL, Teixeira TF \& Britski HA. 2016. Two new species of Leporinus Agassiz, 1929 (Characiformes: Anostomidae) from tributaries of the lower Amazon basin in Brazil. Zootaxa, 4178(1), 97-115.

Borodin NA. 1929. Notes on some species and subspecies of the genus Leporinus Spix. Museum.

Ovchynnyk MM. 1971. Unrecorded and new species of fishes from fresh waters of Ecuador. Zoologischer Anzeiger, 187(1-2), 82-122.

Fowler HW. 1943. A collection of fresh-water fishes from Colombia, obtained chiefly by Brother Nicéforo Maria. Proceedings of the Academy of Natural Sciences of Philadelphia, 223-266.
Eigenmann CH. 1924. The Fishes of Western South America: Part I.: The Freshwater Fishes of Northwestern South America, Including Colombia, Panama, and the Pacific Slopes of Ecuador and Peru, Together with an Appendix Upon the Fishes of the Rio Meta in Colombia. (Vol. 9, No. 1). authority of the Board of trustees of the Carnegie institute.

Eigenmann CH \& Ogle F. 1907. An annotated list of characin fishes in the United States National Museum and the Museum of Indiana University, with descriptions of new species. Proceedings of the United States National Museum.

Fowler HW. 1940. Zoological results of the second Bolivian expedition for the Academy of Natural Sciences of Philadelphia, 1936-1937. Part I: the fishes. Proceedings of the Academy of Natural Sciences of Philadelphia, 92, 43-103.

Marinho MM \& Menezes NA. 2017. Taxonomic review of Copella (Characiformes: Lebiasinidae) with an identification key for the species. PloS one, 12(8), e0183069.

Zarske A. 2009. Nannostomus rubrocaudatus sp. n.-ein neuer Ziersalmler aus Peru (Teleostei: Characiformes: Lebiasinidae). Vertebrate Zoology, 59(1), 11-23.

Steindachner F. 1876. Ichthyologische Beiträge (IV)[With subtitles i-iv.]. Sitzungsberichte der Kaiserlichen Akademie der Wissenschaften. Mathematisch-Naturwissenschaftliche Classe, 72(1), 551-616.

Myers GS \& Ternetz C. 1927. Descriptions of new South American fresh-water fishes collected by Dr. Carl Ternetz. Museum.

Toledo-Piza M, Menezes NA \& dos Santos GM. 1999. Revision of the neotropical fish genus Hydrolycus (Ostariophysi: Cynodontinae) with description of two new species.

Ota RP, Py-Daniel LHR \& Jégu M. 2016. A new silver dollar species of Metynnis Cope, 1878 (Characiformes: Serrasalmidae) from northwestern Brazil and southern Venezuela. Neotropical Ichthyology, 14(4).

Eigenmann CH. 1908. Preliminary descriptions of new genera and species of tetragonopterid characins (Zoölogical Results of the Thayer Brazilian expedition.). Bulletin of the Museum of Comparative Zoology, 52(6), 91-106.

Ruiz-C RI, Román-Valencia C, Taphorn DC, Buckup PA \& Ortega H. 2018. Revision of the Astyanax orthodus species-group (Teleostei: Characidae) with descriptions of three new species. European Journal of Taxonomy.

Garcia-Ayala JR, Ohara WM, Pastana MN \& Benine RC. 2017. A new species of Brachychalcinus (Characiformes: Characidae) from the rio Xingu basin, Serra do Cachimbo, Brazil. Zootaxa, 4362(4), 564-574.

Menezes NA \& Lucena CASD. 2014. A taxonomic review of the species of Charax Scopoli, 1777 (Teleostei: Characidae: Characinae) with description of a new species from the rio Negro bearing superficial neuromasts on body scales, Amazon basin, Brazil. Neotropical Ichthyology, 12(2), 193228.

Vanegas-Ríos JA, Urbano-Bonilla A \& Azpelicueta M. 2015. Chrysobrycon guahibo, a new species from the Orinoco River basin, with a distribution expansion of the genus (Teleostei: Characidae). Ichthyological Explorations of the Freshwaters, 26, 171-182.

Günther A. 1859. List of the cold-blooded vertebrata collected by Mr. Fraser in the Andes of western Ecuador. In Proceedings of the Zoological Society of London (Vol. 27, pp. 89-93).

Bertaco VA, Malabarba LR, Hidalgo M \& Ortega H. 2007. A new species of Hemibrycon (Teleostei: Characiformes: Characidae) from the río Ucayali drainage, Sierra del Divisor, Peru. Neotropical Ichthyology, 5(3), $251-$ 257.

Lima FC, Correa V \& Ota RP. 2016. A new species of Hemigrammus Gill 1858 (Characiformes: Characidae) from the western Amazon basin in Peru and Colombia. aqua, 22, 123-132.

Zarske A \& Gery J. 2007. Hemigrammus geisleri sp. n. -a new glass characoid fish from the central Amazon basin, with a supplementary description of Hemigrammus minimus BÖHKE, 1955 (Teleostei: Characiformes: Characidae). Vertebrate Zoology 57(1): 5-14 
García-Alzate CA, Lima F, Taphorn DC, Mojica JI, Urbano-Bonilla A \& Teixeira TF. 2020. A new species of Hyphessobrycon Durbin (Characiformes: Characidae) from the western Amazon basin in Colombia and Peru. Journal of Fish Biology.

Zarske A. 2014. Zur Systematik einiger Blutsalmler oder "Rosy Tetras" (Teleostei: Ostariophysi: Characidae). Vertebrate Zoology, 64(2), 139-167.

Zarske A. 2016. Hyphessobrycon margitae spec. nov. ein neuer Salmler aus dem Einzugsgebiet der río Nanay in Peru (Teleostei: Characiformes: Characidae). Vertebrate Zoology, 66, 105-115

García-Alzate CA, Román-Valencia C \& Ortega H. 2013. Hyphessobrycon taphorni y H. eschwartzae (Teleostei: Characidae) dos nuevas especies de peces de la cuenca del río Madre de Dios, Perú. Revista de Biología Tropical, 61(2), 859-873.

Zarske A \& Géry J. 1997 Hyphessobrycon frankei sp. n. Beschreibung eines neuen Salmlers aus dem Einzugsgebiet des Río Ucayali in Peru (Teleostei: Characidae: Tetragonopterinae). Datz - Sonderheft 50(5): 308-312.

Mirande JM. 2010. Phylogeny of the family Characidae (Teleostei: Characiformes): from characters to taxonomy. Neotropical Ichthyology, 8(3), 385-568.

Zarske A. 2008. Knodus borki sp. n.-ein neuer Salmler aus Peru mit einer ergänzenden Beschreibung von Boehlkea fredcochui Géry, 1966 (Teleostei: Characiformes: Characidae). Vertebrate Zoology, 58(2), 159-171.

Géry J. 1964. Upper Amazonian characoid fishes collected by Mr. Jack Roberts. Tropical Fish Hobbyist, 13(4), 21-32.

Fowler HW. 1906. Further knowledge of some heterognathous fishes. Part II. Proceedings of the Academy of Natural Sciences of Philadelphia, 431-483.

Marinho MM \& Langeani F. 2010. A new species of Moenkhausia from the rio Amazonas and rio Orinoco basins (Characiformes: Characidae). Zootaxa, 2577(1), 57-68.

Böhlke J. 1958. Studies on fishes of the family Characidae.: No. 14. A report on several extensive recent collections from Ecuador. Proceedings of the Academy of Natural Sciences of Philadelphia, 110, 1-121.

Vanegas-Ríos JA, Faustino-Fuster DR, Meza-Vargas V \& Ortega H. 2020. Phylogenetic relationships of a new genus and species of stevardiine fish (Characiformes: Characidae: Stevardiinae) from the Río Amazonas basin, Peru. Journal of Zoological Systematics and Evolutionary Research, 58(1), 387-407.

Ovchynnyk MM. 1967. Freshwater Fishes of Ecuador and Perspective for Development of Fish Cultivation (No. 1). Latin American Studies Center, Michigan State University.

Géry J. 1961. Three new South American characids. Tropical Fish Hobbyist, 9(9) 26-46.

Steindachner F. 1882. Beiträge zur Kenntniss der Flussfische Südamerikas: IV. aus der Kaiserlich-Königlichen Hof-und Staatsdruckerei, in commission bei Karl Gerold's Sohn, Buchhändler der Kaiserlichen Akademie der Wissenschaften.

Müller J \& Troschel FH. 1844. Synopsis generum et specierum familiae Characinorum (Prodomus descriptionis novorum generum et specierum). Archiv für Naturgeschichte, 10(1), 81-99.

Cope ED. 1871. On the fishes of the Ambyiacu River. Proceedings of the Academy of Natural Sciences of Philadelphia, 250-294.

Fowler HW. 1945. Colombian Zoological Survey. Part I: The Fresh-Water Fishes Obtained in 1945. Proceedings of the Academy of Natural Sciences of Philadelphia, 97, 93-135.

Ortega H \& Vari RP. 1986. Annotated checklist of the freshwater fishes of Peru. Smithsonian Contributions to Zoology.

Lucena ZMSD \& Malabarba LR. 2010. Descrição de nove espécies novas de Phenacogaster (Ostariophysi: Characiformes: Characidae) e comentários sobre as demais espécies do gênero. Zoologia (Curitiba), 27(2), 263-304.

Howes G. 1982. Review of the genus Brycon (Teleostei: Characoidei).

Zanata AM \& Toledo-Piza M. 2004. Taxonomic revision of the South American fish genus Chalceus Cuvier (Teleostei: Ostariophysi: Characiformes) with the description of three new species. Zoological Journal of the Linnean Society, 140(1), 103-135.
Weitzman SH \& Kanazawa RH. 1976. Ammocryptocharax elegans, a new genus and species of riffle-inhabiting characoid fish (Teleostei: Characidae) from South America.

Eigenmann CH. 1909. Reports on the expedition to British Guiana the Indiana University and the Carnegie Museum; 1908. Ann. Carnegie Mus., 6, 4-54.

Buckup PA. 1993. Review of the characidiin fishes (Teleostei: Characiformes), with descriptions of four new genera and ten new species. Ichthyological Exploration of Freshwaters, 4(2), 97-154.

Melo MR, Buckup PA \& Oyakawa OT. 2016. A new species of Characidium Reinhardt, 1867 (Characiformes: Crenuchidae) endemic to the Atlantic Forest in Paraná State, southern Brazil. Neotropical Ichthyology, 14(3).

Reis RE, Kullander SO \& Ferraris CJ. 2003. Check list of the freshwater fishes of South and Central America. Edipucrs.

Waltz BT \& Albert JS. 2018. New species of glass knifefish Eigenmnnia loretana (Gymnotiformes: Sternopygidae) from the Western Amazon. Zoota$x a, 4399(3), 399-411$

de Santana CD \& Crampton WG. 2010. A review of the South American electric fish genus Porotergus (Gymnotiformes: Apteronotidae) with the description of a new species. Copeia, 2010(1), 165-175.

Bernt MJ, Crampton WG, Orfinger AB \& Albert JS. 2018. Melanosternarchus amaru, a new genus and species of electric ghost knifefish (Gymnotiformes: Apteronotidae) from the Amazon Basin. Zootaxa, 4378(4), 451-479.

Lundberg JG, Fernandes CC, Campos-Da-Paz R \& Sullivan JP. 2013. Sternarchella calhamazon n. sp., the Amazon's most abundant species of apteronotid electric fish, with a note on the taxonomic status of Sternarchus capanemae Steindachner, 1868 (Gymnotiformes, Apteronotidae). Proceedings of the Academy of Natural Sciences of Philadelphia, 162(1), $157-173$

Evans KM, Crampton WG \& Albert JS. 2017. Taxonomic revision of the deep channel electric fish genus Sternarchella (Teleostei: Gymnotiformes: Apteronotidae), with descriptions of two new species. Neotropical Ichthyology, 15(2).

Bernt MJ, Fronk AH, Evans KM \& Albert JS. 2020. A redescription of deep-channe ghost knifefish, Sternarchogiton preto (Gymnotiformes: Apteronotidae), with assignment to a new genus. Neotropical Ichthyology, 18(1).

Crampton WG, Santana CDD, Waddell JC \& Lovejoy NR. 2016. A taxonomic revision of the Neotropical electric fish genus Brachyhypopomus (Ostariophysi: Gymnotiformes: Hypopomidae), with descriptions of 15 new species. Neotropical Ichthyology, 14(4).

Sullivan JP, Zuanon J \& Fernandes CC. 2013. Two new species and a new subgenus of toothed Brachyhypopomus electric knifefishes (Gymnotiformes, Hypopomidae) from the central Amazon and considerations pertaining to the evolution of a monophasic electric organ discharge. ZooKeys, (327), 1

de Santana CD \& Crampton WG. 2011. Phylogenetic interrelationships, taxonomy, and reductive evolution in the Neotropical electric fish genus Hypopygus (Teleostei, Ostariophysi, Gymnotiformes). Zoological Journal of the Linnean Society, 163(4), 1096-1156.

Crampton WG, Lovejoy NR \& Albert JS. 2003. Gymnotus ucamara: a new species of Neotropical electric fish from the Peruvian Amazon (Ostariophysi: Gymnotidae), with notes on ecology and electric organ discharges. Zootaxa, 277(1), 1-18.

Craig JM, Kim LY, Tagliacollo VA \& Albert JS. 2019. Phylogenetic revision of Gymnotidae (Teleostei: Gymnotiformes), with descriptions of six subgenera. PloS one, 14(11), e0224599.

Burgess WE. 1989. An atlas of freshwater and marine catfishes. A preliminary survey of the Siluriformes. TFH Publication, Neptune City, Canada, 28 305-325

Birindelli JL. 2014. Phylogenetic relationships of the South American Doradoidea (Ostariophysi: Siluriformes). Neotropical Ichthyology, 12(3), 451-564.

Birindelli JL \& Sabaj-Pérez MH. 2011. Ossancora, new genus of thorny catfish (Teleostei: Siluriformes: Doradidae) with description of one new species. Proceedings of the Academy of Natural Sciences of Philadelphia, 161(1), 117-152. 
Peters W. 1877. Über die von Dr. C. Sachs in Venezuela gesammelten Fische. Monatsberichte der Königlichen Preussische Akademie des Wissenschaften zu Berlin, 1877, 469-473.

Sabaj MH. \& Arce M. 2017. Taxonomic assessment of the Hard-Nosed Thornycats (Siluriformes: Doradidae: Trachydoras Eigenmann 1925) with description of Trachydoras gepharti, n. sp. Proceedings of the Academy of $\mathrm{Na}$ tural Sciences of Philadelphia, 166(1), 1-53.

Sabaj-Pérez, MH, Arce M, Sousa LM \& Birindelli JL. 2014. Nemadoras cristinae, new species of thorny catfish (Siluriformes: Doradidae) with redescriptions of its congeners. Proceedings of the Academy of Natural Sciences of Philadelphia, 163(1), 133-178.

Rocha M, Rossoni F, Akama A \& Zuanon J. 2020. A new species of spiny driftwood catfish Spinipterus (Siluriformes: Auchenipteridae) from the Amazon basin. Journal of Fish Biology, 96(1), 243-250.

Calegari BB, Vari RP. \& Reis RE. 2019. Phylogenetic systematics of the driftwood catfishes (Siluriformes: Auchenipteridae): a combined morphological and molecular analysis. Zoological Journal of the Linnean Society, 187(3), 661-773.

Grant S. 2015. Four new subgenera of Centromochlus Kner, 1858 with comments on the boundaries of some related genera (Siluriformes: Auchenipteridae: Centromochlinae). Ichthyofile, 3, 1-16

Akama A \& Ferraris JrCJ 2011. Spinipterus, a new genus of small, spiny catfish (Siluriformes: Auchenipteridae) from the Peruvian Amazon. Zoota$x a$, 2992(1), 52-60.

Walsh SJ, Ribeiro FRV \& Py-Daniel LHR. 2015. Revision of Tympanopleura Eigenmann (Siluriformes: Auchenipteridae) with description of two new species. Neotropical Ichthyology, 13(1), 1-46.

Greenfield DW, Glodek GS. 1977. Trachelyichthys exilis, a new species of catfish (Pisces: Auchenipteridae) from Peru. Fieldiana: Zoology 72: 47-58

Lundberg JG \& Akama A. 2005. Brachyplatystoma capapretum: a new species of goliath catfish from the Amazon basin, with a reclassification of allied catfishes (Siluriformes: Pimelodidae). Copeia, 2005(3), 492-516.

Parisi BM, Lundberg JG \& Donascimiento C. 2006. Propimelodus caesius a new species of long finned pimelodid catfish (Teleostei: Siluriformes) from the Amazon Basin, South America. Proceedings of the Academy of Natural Sciences of Philadelphia, 67-78.

Haseman JD. 1911. Descriptions of some new species of fishes and miscellaneous notes on others obtaines during the expedition of the Carnegie Museum to Central South America.

Littmann MW, Lundberg JG \& Rocha MS. 2021. Revision of the South American catfish genus Hypophthalmus (Siluriformes, Pimelodidae) with descriptions of two new species from the Amazon and Orinoco Basins. Proceedings of the Academy of Natural Sciences of Philadelphia, 167(1), $171-223$

Faustino-Fuster DR \& Ortega H. 2020. A new species of Mastiglanis Bockmann 1994 (Siluriformes: Heptapteridae) from the Amazon River basin, Peru. Zootaxa, 4820(2), zootaxa-4820.

Faustino-Fuster DR \& de Souza LS. 2021. A new species of Cetopsorhamdia (Siluriformes: Heptapteridae) from the Upper Amazon River basin. Journal of fish biology. https://doi.org/10.1111/jfb.14914

Nijssen H \& Isbrücker IJH. 1980. A review of the genus Corydoras Lacépède, 1803. Bijdragen tot de Dierkunde, 50(1), 190-220.

Orcés-Villagomez G. 1960. Peces ecuatorianos de la familia Callichthyidae, con la descripción de una especie nueva. Ciencia y Naturaleza, 3(1), 3-8.

Nijssen H \& Isbriicker IJH. 1986. Cinq espèces nouvelles de poisons chats cuirassés du genre Corydoras Lacepède, 1893, du Pérou et de l'Equateur (Pisces, Siluriformes, Callichthyidae). Revue fr. Aquariol, 12(3), 65-76.

Weitzman SH. 1960. Figures and descriptions of four South American catfishes of the genus Corydoras, including two new species. Stanford Ichthyological Bulletin, 7, 140-154.

Ferraris CJ. 2007. Checklist of catfishes, recent and fossil (Osteichthyes: Siluriformes), and catalogue of siluriform primary types. Zootaxa, 1418(1), $1-628$.
Isbrücker IJH \& Nijssen H. 1988. Acanthicus adonis, ein neuer Harnischwels aus dem Rio Tocantins, Brasilien (Pisces, Siluriformes, Loricariidae). Die Aquarien-und Terrarien-Zeitschrift, 41, 164-167.

Ray CK \& Armbruster JW. 2016. The genera Isorineloricaria and Aphanotorulus (Siluriformes: Loricariidae) with description of a new species. Zoota$x a, 4072(5)$, 501-539.

Fowler HW. 1939. A collection of fishes obtained by Mr. William C. Morrow in the Ucayali River Basin, Peru. Proceedings of the Academy of Natural Sciences of Philadelphia, 91, 219-289.

Armbruster JW. 2004. Phylogenetic relationships of the suckermouth armoured catfishes (Loricariidae) with emphasis on the Hypostominae and the Ancistrinae. Zoological Journal of the Linnean Society, 141(1), 1-80.

Lujan NK \& Chamon C. 2008. Two new species of Loricariidae (Teleostei: Siluriformes) from main channels of the upper and middle Amazon Basin, with discussion of deep-water specialization in loricariids. Ichthyological Exploration of Freshwaters, 19, 271-282.

Isbrücker IJH, Seidel I, Michels JP, Schraml E \& Werner A. 2001. Diagnose vierzehn neuer Gattungen der Familie Loricariidae Rafinesque, 1815 (Teleostei, Ostariophysi). Datz-Sonderheft Harnischwelse, 2, 17-24.

Aquino AE \& Schaefer SA. 2010. Systematics of the genus Hypoptopoma Günther, 1868 (Siluriformes, Loricariidae). Bulletin of the American Museum of Natural History, 2010(336), 1-110.

Ray CK \& Armbruster JW. 2016. The genera Isorineloricaria and Aphanotorulus (Siluriformes: Loricariidae) with description of a new species. Zoota $x a, 4072(5)$, 501-539.

Reis RE. 2004. Otocinclus cocama, a new uniquely colored loricariid catfish from Peru (Teleostei: Siluriformes), with comments on the impact of taxonomic revisions to the discovery of new taxa. Neotropical Ichthyology, 2(3), 109-115

Chockley BR \& Armbruster JW. 2002. Panaque changae, a new species of catfish (Siluriformes: Loricariidae) from eastern Peru. Ichthyological Explora tion of Freshwaters, 13(1), 81-90.

Cope ED. 1874. On some Batrachia and Nematognathi brought from the upper Amazon by Prof. Orton. Proceedings of the Academy of Natural Sciences of Philadelphia, 120-137.

Carvalho TP, Reis RE \& Sabaj MH. 2017. Description of a new blind and rare species of Xyliphius (Siluriformes: Aspredinidae) from the Amazon basin using high-resolution computed tomography. Copeia, 105(1), 14-28.

Fels JF \& De Rham P. 1981. Recentes collectes de Rivulus (Cyprinodontidés) au Pérou, avec description de six nouvelles espèces.

Costa W. 2003. Two new annual fishes of the genus Moema Costa, 1989, from the Peruvian Amazon (Teleostei, Cyprinodontiformes, Rivulidae). Boletim do Muse Nacional, Série Zoologia (513): 1-10

Valdesalici S, Nielsen DTB \& Pillet D. 2015. Moema beucheyi (Teleostei: Cyprinodontiformes: Rivulidae), a new annual killifish from the Río Madeira basin, Bolivian Amazon. aqua, 21(3-15), 128.

Costa W. 2003. Three new annual fishes of the genus Aphyolebias Costa, 1998 (Cyprinodontiformes: Rivulidae) from Bolivian and Peruvian Amazon. Comunicações do Museu de Ciências e Tecnologia da PUCRS, Série Zoologia, 16(2), 155-166

Sant'Anna VB, Delapieve MLS \& Reis RE. 2012. A new species of Potamorrhaphis (Beloniformes: Belonidae) from the Amazon Basin. Copeia, 2012(4), 663-669.

Favorito SE, Zanata AM \& Assumpção MI. 2005. A new Synbranchus (Teleostei: Synbranchiformes: Synbranchidae) from ilha de Marajó, Pará, Brazil, with notes on its reproductive biology and larval development. Neotropical Ichthyology, 3(3), 319-328.

Casatti L \& Chao NL. 2002. A new species of Pachyurus Agassiz 1831 (Teleostei, Perciformes, Sciaenidae) from the Río Napo basin, eastern Ecuador. Zootaxa, 38(1), 1-7.

Romer U, Beninde J, Duponchelle F, Díaz AV, Ortega H, Hahn I, ... \& Renno JF. 2012. Description of Apistogramma allpahuayo sp. n., a new dwarf cichlid species (Teleostei: Perciformes: Geophaginae) from in and around the Reserva Nacional Allpahuayo Mishana, Loreto, Peru. Vertebrate Zoology, 189-212. 
Romer U, Duponchelle F, Diaz AV, García- Dávila C, Sirvas S \& Catchay CD. 2011. Apistogramma cinilabra sp. n.: Description of a potentially endangered endemic cichlid species (Teleostei: Perciformes: Cichlidae) from the Departamento Loreto, Peru. Vertebrate Zoology, 61(1), 115-135.

Ready JS \& Kullander SO. 2004. Apistogramma eremnopyge, a new species of cichlid fish (Teleostei: Cichlidae) from Peru. Zootaxa, 564(1), 1-10.

Römer U, Soares DP, García- Dávila C, Duponchelle F, Renno JF \& Hahn I. 2015. Re-description of Apistogramma payaminonis Kullander, 1986, with descriptions of two new cichlid species of the genus Apistogramma (Teleostei, Perciformes, Geopha-ginae) from northern Peru. Vertebrate Zoology, 65(3), 287-314.

Römer U, Römer Cl, Estivals G, Díaz AV, Duponchelle F, García- Dávila C, ... \& Renno JF. 2017. Description of a new maternal larvophilic mouth-brooding cichlid species, Apistogramma megastoma sp. n. (Teleostei: Perciformes: Geophaginae), from Loreto, Peru. Vertebrate Zooogy, 67(2), 1-20.

Britzke R, Oliveira C \& Kullander SO. 2014. Apistogramma ortegai (Teleostei: Cichlidae), a new species of cichlid fish from the Ampyiacu River in the Peruvian Amazon basin. Zootaxa, 409-419.
Römer U, Beninde J, Duponchelle F \& García- Dávila C. 2013. Description of Apistogramma paulmuelleri sp. n., a new geophagine cichlid species (Teleostei: Perciformes) from the Amazon river basin in Loreto, Peru. Vertebrate Zoology, 63(1), 15-34.

Römer U, Hahn I, Römer E, Soares DP \& Wöhler M. 2003. Apistogramma martin sp. n. Beschreibung eines geophaginen Zwergcichliden (Teleostei: Perciformes) aus dem nördlichen Peru. -Das Aquarium, 37(4), 406.

Kullander SO. 1979. Description of a new species of the genus Apistogramma (Teleostei, Perciformes, Cichlidae) from Peru.

Arbour JH, Salazar REB \& López-Fernández H. 2014. A New Species of Bujurquina (Teleostei: Cichlidae) from the Río Danta, Ecuador, with a Key to the Species in the Genus. Copeia, 2014(1), 79-86.

Cope ED. 1871. On the fishes of the Ambyiacu River. Proceedings of the Academy of Natural Sciences of Philadelphia, 250-294.

Kullander SO. 1986. Cichlid fishes of the Amazon River drainage of Peru. Department of Vertebrate Zoology, Research Division, Swedish Museum of Natural History.

da Costa Ramos RT. 2003. Systematic review of Apionichthys (Pleuronectiformes: Achiridae), with description of four new species. Ichthyological Exploration of Freshwaters, 14(2), 97-126.

Appendix 2. List of fish species of the department of Loreto. Columns are organized by Order, family, valid name, restricted distribution (RD) $=\mathrm{x}$, commercial species (C) $=*$ following Garcia-Dávila et al. (2018) and, IUCN categorization (LC=Least Concern, DD= Data Deficient, NT= Near Threatened, CR=Critically Endangered, EN=Endangered, VU=Vulnerable).

\begin{tabular}{|c|c|c|c|c|}
\hline Order / Family & Species & RD & C & IUCN \\
\hline \multicolumn{5}{|l|}{ Myliobatiformes } \\
\hline \multirow[t]{2}{*}{ Potamotrygonidae } & Plesiotrygon nana Carvalho \& Ragno 2011 & & & \\
\hline & Paratrygon aiereba (Müller \& Henle 1841) & & & \\
\hline & Potamotrygon motoro (Müller \& Henle 1841) & & & \\
\hline & Potamotrygon orbignyi (Castelnau 1855) & & & LC \\
\hline & Potamotrygon tigrina Carvalho, Sabaj Pérez \& Lovejoy 2011 & & & EN \\
\hline \multicolumn{5}{|l|}{ Lepidosireniformes } \\
\hline Lepidosirenidae & Lepidosiren paradoxa Fitzinger 1837 & & & \\
\hline \multicolumn{5}{|l|}{ Osteoglossiformes } \\
\hline Arapaimidae & Arapaima gigas (Schinz 1822) & & $*$ & DD \\
\hline Osteoglossidae & Osteoglossum bicirrhosum (Cuvier 1829) & & $*$ & \\
\hline \multicolumn{5}{|l|}{ Clupeiformes } \\
\hline \multirow[t]{9}{*}{ Engraulidae } & Amazonsprattus scintilla Roberts 1984 & & & LC \\
\hline & Anchoviella alleni (Myers 1940) & & & LC \\
\hline & Anchoviella carrikeri Fowler 1940 & & & LC \\
\hline & Anchoviella guianensis (Eigenmann 1912) & & & LC \\
\hline & Anchoviella hernanni Loeb, Varella \& Menezes 2018 & & & LC \\
\hline & Anchoviella jamesi (Jordan \& Seale 1926) & & & LC \\
\hline & Anchoviella juruasanga Loeb 2012 & & & LC \\
\hline & Jurengraulis juruensis (Boulenger 1898) & & & LC \\
\hline & Lycengraulis batesii (Günther 1868) & & & LC \\
\hline \multirow[t]{6}{*}{ Pristigasteridae } & Ilisha amazonica (Miranda Ribeiro 1920) & & & LC \\
\hline & Pellona altamazonica Cope 1872 & $x$ & & \\
\hline & Pellona castelnaeana Valenciennes 1847 & & $*$ & LC \\
\hline & Pellona flavipinnis (Valenciennes 1837) & & $*$ & LC \\
\hline & Pristigaster cayana Cuvier 1829 & & & LC \\
\hline & Pristigaster whiteheadi Menezes \& de Pinna 2000 & & & LC \\
\hline \multicolumn{5}{|l|}{ Characiformes } \\
\hline \multirow[t]{5}{*}{ Hemiodontidae } & Anodus elongatus Agassiz 1829 & & $*$ & \\
\hline & Bivibranchia fowleri (Steindachner 1908) & & & \\
\hline & Hemiodus argenteus Pellegrin 1909 & & & \\
\hline & Hemiodus atranalis (Fowler 1940) & & & \\
\hline & Hemiodus gracilis Günther 1864 & & & \\
\hline
\end{tabular}




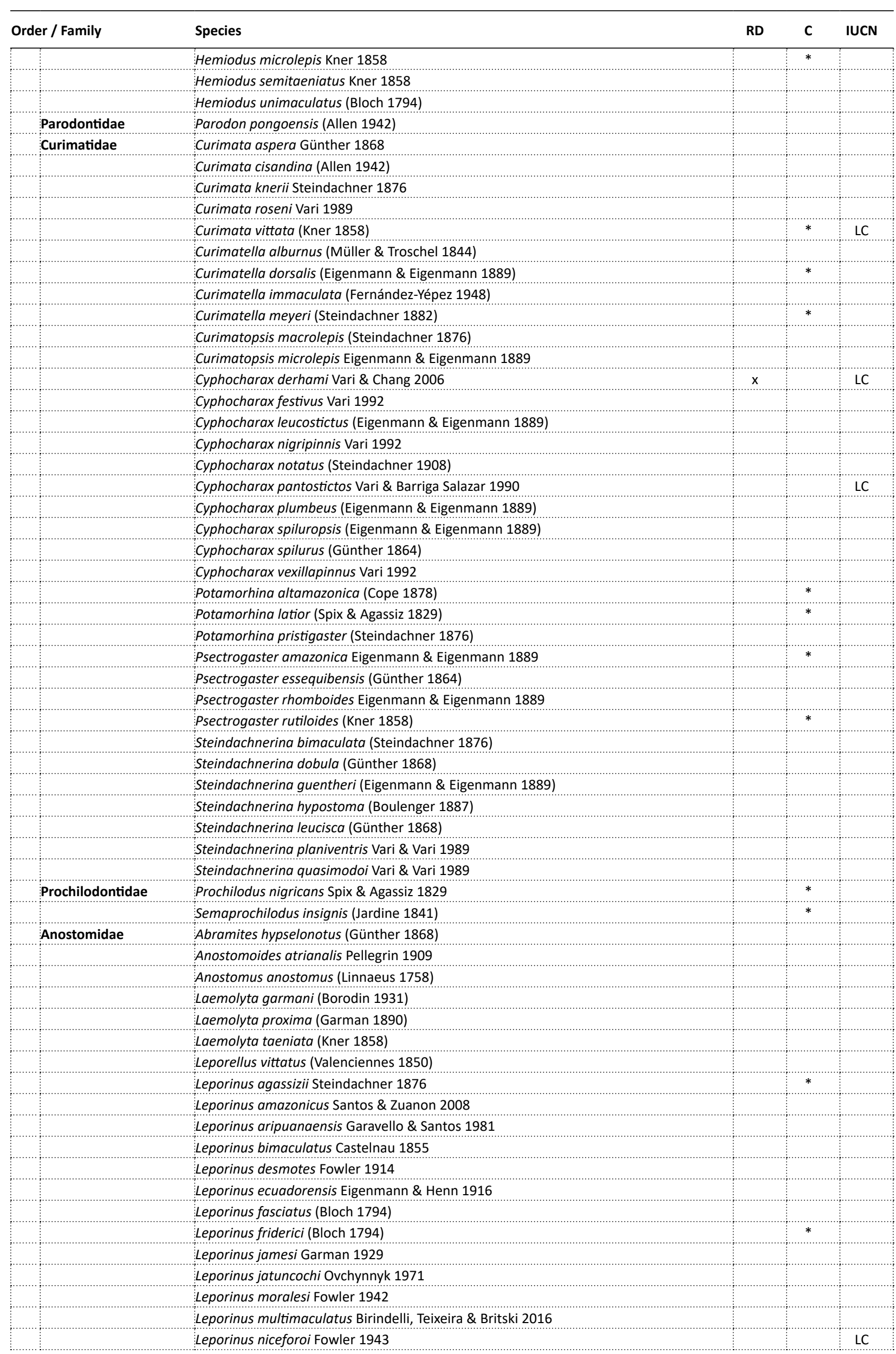




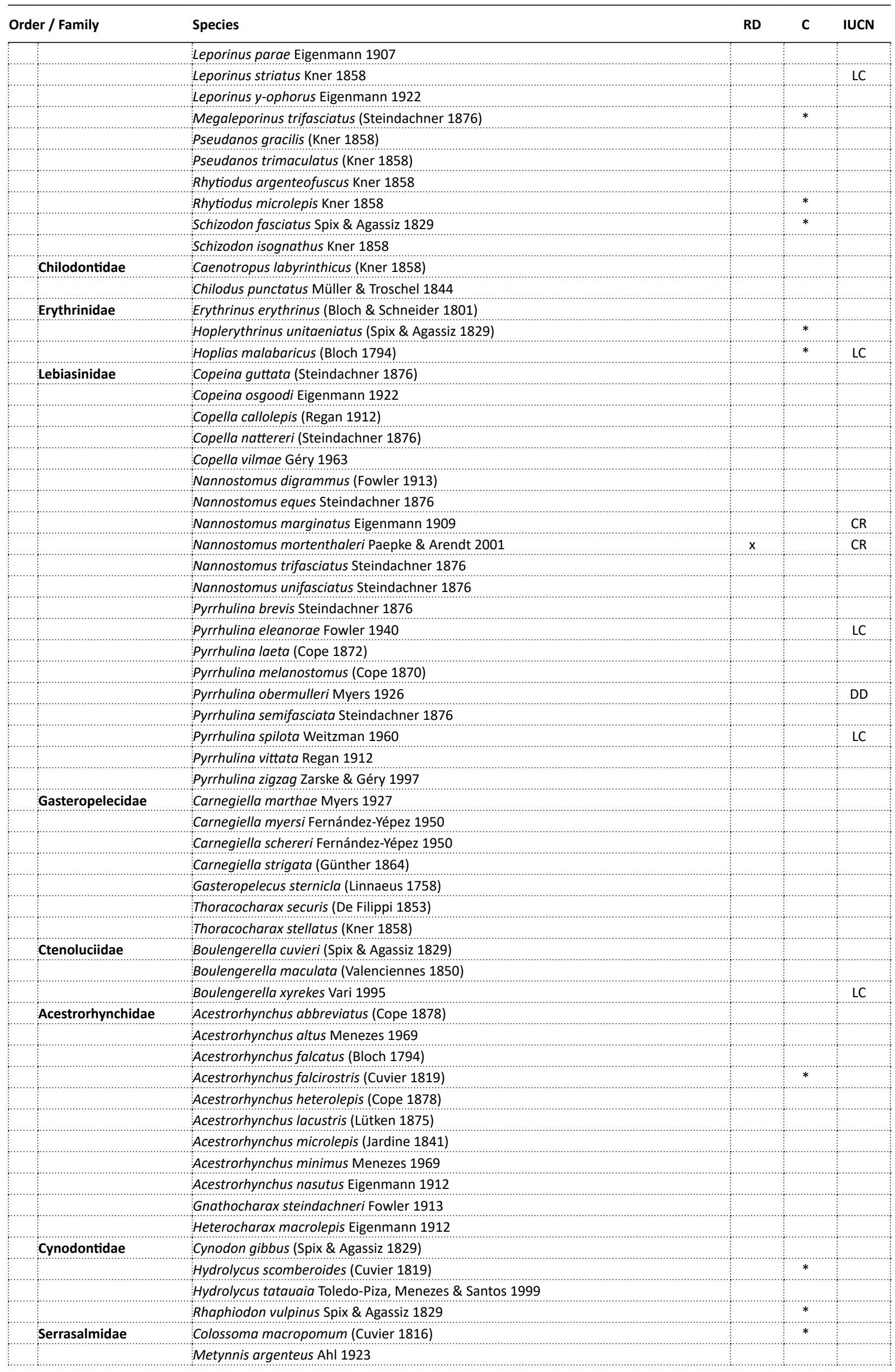




\begin{tabular}{|c|c|c|c|c|}
\hline Order / Family & Species & RD & C & IUCN \\
\hline & Metynnis hypsauchen (Müller \& Troschel 1844) & & & \\
\hline & Metynnis lippincottianus (Cope 1870) & & & \\
\hline & Metynnis luna Cope 1878 & & & \\
\hline & Metynnis maculatus (Kner 1858) & & & \\
\hline & Myloplus levis (Eigenmann \& McAtee 1907) & & & \\
\hline & Myloplus rubripinnis (Müller \& Troschel 1844) & & $*$ & \\
\hline & Myloplus schomburgkii (Jardine 1841) & & $*$ & \\
\hline & Myloplus torquatus (Kner 1858) & & & \\
\hline & Mylossoma albiscopum (Cope 1872) & & $*$ & \\
\hline & Mylossoma aureum (Spix \& Agassiz 1829) & & $*$ & \\
\hline & Mylossoma duriventre (Cuvier 1818) & & & \\
\hline & Piaractus brachypomus (Cuvier 1818) & & $*$ & \\
\hline & Pristobrycon striolatus (Steindachner 1908) & & & \\
\hline & Pygocentrus nattereri Kner 1858 & & $*$ & \\
\hline & Serrasalmus eigenmanni Norman 1929 & & & \\
\hline & Serrasalmus elongatus Kner 1858 & & $*$ & \\
\hline & Serrasalmus humeralis Valenciennes 1850 & & & \\
\hline & Serrasalmus maculatus Kner 1858 & & & \\
\hline & Serrasalmus rhombeus (Linnaeus 1766) & & $*$ & \\
\hline & Serrasalmus spilopleura Kner 1858 & & & \\
\hline Characidae & Acestrocephalus boehlkei Menezes 1977 & & & LC \\
\hline & Aphyocharax nattereri (Steindachner 1882) & & & \\
\hline & Aphyocharax pusillus Günther 1868 & & & \\
\hline & Astyanax abramis (Jenyns 1842) & & & \\
\hline & Astyanax bimaculatus (Linnaeus 1758) & & & \\
\hline & Astyanax gandhiae Ruiz-C., Román-Valencia, Taphorn, Buckup \& Ortega 2018 & & & \\
\hline & Astyanax kennedyi Géry 1964 & $x$ & & DD \\
\hline & Astyanax longior (Cope 1878) & & & DD \\
\hline & Astyanax maximus (Steindachner 1876) & & & \\
\hline & Astyanax multidens (Pearson 1924) & & & \\
\hline & Astyanax symmetricus Eigenmann 1908 & & & \\
\hline & Astyanax villwocki Zarske \& Géry 1999 & & & DD \\
\hline & Attonitus irisae Vari \& Ortega 2000 & & & LC \\
\hline & Axelrodia stigmatias (Fowler 1913) & & & \\
\hline & Bario steindachneri (Eigenmann 1893) & & & \\
\hline & Boehlkea fredcochui Géry 1966 & & & \\
\hline & Brachychalcinus copei (Steindachner 1882) & & & \\
\hline & Brachychalcinus nummus Böhlke 1958 & & & LC \\
\hline & Brachychalcinus orbicularis (Valenciennes 1850) & & & \\
\hline & Bryconamericus bolivianus Pearson 1924 & & & LC \\
\hline & Bryconamericus diaphanus (Cope 1878) & & & LC \\
\hline & Bryconamericus pachacuti Eigenmann 1927 & & & LC \\
\hline & Bryconamericus phoenicopterus (Cope 1872) & & & LC \\
\hline & Bryconella pallidifrons (Fowler 1946) & & & \\
\hline & Ceratobranchia binghami Eigenmann 1927 & & & LC \\
\hline & Ceratobranchia obtusirostris Eigenmann 1914 & & & LC \\
\hline & Charax caudimaculatus Lucena 1987 & & & \\
\hline & Charax gibbosus (Linnaeus 1758) & & & \\
\hline & Charax michaeli Lucena 1989 & & & \\
\hline & Charax niger Lucena 1989 & & & \\
\hline & Charax tectifer (Cope 1870) & & & LC \\
\hline & Cheirodon luelingi Géry 1964 & & & DD \\
\hline & Cheirodon ortegai Vari \& Géry 1980 & & & LC \\
\hline & Chrysobrycon eliasi Vanegas-Ríos, Azpelicueta \& Ortega 2011 & & & DD \\
\hline & Chrysobrycon guahibo Vanegas-Ríos, Urbano-Bonilla \& Azpelicueta 2015 & & & \\
\hline & Chrysobrycon hesperus (Böhlke 1958) & & & LC \\
\hline & Chrysobrycon myersi (Weitzman \& Thomerson 1970) & & & LC \\
\hline & Creagrutus amoenus Fowler 1943 & & & LC \\
\hline & Creagrutus anary Fowler 1913 & & & \\
\hline & Creagrutus barrigai Vari \& Harold 2001 & & & \\
\hline & Creagrutus changae Vari \& Harold 2001 & & & LC \\
\hline & Creagrutus cochui Géry 1964 & & & \\
\hline
\end{tabular}




\begin{tabular}{|c|c|c|c|c|}
\hline Order / Family & \multirow{2}{*}{$\begin{array}{l}\text { Species } \\
\text { Creagrutus flavescens Vari \& Harold } 2001\end{array}$} & \multirow[t]{2}{*}{ RD } & \multirow[t]{2}{*}{ C } & \multirow{2}{*}{ IUCN } \\
\hline & & & & \\
\hline & Creagrutus gephyrus Böhlke \& Saul 1975 & & & $\mathrm{LC}$ \\
\hline & Creagrutus gracilis Vari \& Harold 2001 & & & LC \\
\hline & Creagrutus holmi Vari \& Harold 2001 & & & LC \\
\hline & Creagrutus kunturus Vari, Harold \& Ortega 1995 & & & $\mathrm{LC}$ \\
\hline & Creagrutus muelleri (Günther 1859) & & & LC \\
\hline & Creagrutus occidaneus Vari \& Harold 2001 & & & \\
\hline & Creagrutus ortegai Vari \& Harold 2001 & & & LC \\
\hline & Creagrutus peruanus (Steindachner 1876) & & & LC \\
\hline & Creagrutus pila Vari \& Harold 2001 & & & $\mathrm{LC}$ \\
\hline & Creagrutus ungulus Vari \& Harold 2001 & & & LC \\
\hline & Ctenobrycon hauxwellianus (Cope 1870) & & & \\
\hline & Cynopotamus amazonum (Günther 1868) & & & \\
\hline & Galeocharax gulo (Cope 1870) & & & \\
\hline & Gephyrocharax major Myers 1929 & & & LC \\
\hline & Gymnocorymbus ternetzi (Boulenger 1895) & & & \\
\hline & Gymnocorymbus thayeri Eigenmann 1908 & & & \\
\hline & Hemibrycon divisorensis Bertaco, Malabarba, Hidalgo \& Ortega 2007 & $\mathrm{x}$ & & $\mathrm{DD}$ \\
\hline & Hemibrycon huambonicus (Steindachner 1882) & & & $\mathrm{LC}$ \\
\hline & Hemibrycon jabonero Schultz 1944 & & & \\
\hline & Hemibrycon jelskii (Steindachner 1876) & & & \\
\hline & Hemibrycon polyodon (Günther 1864) & & & $\mathrm{LC}$ \\
\hline & Hemigrammus aguaruna Lima, Correa \& Ota 2016 & & & \\
\hline & Hemigrammus analis Durbin 1909 & & & \\
\hline & Hemigrammus bellottii (Steindachner 1882) & & & \\
\hline & Hemigrammus geisleri Zarske \& Géry 2007 & & & \\
\hline & Hemigrammus hyanuary Durbin 1918 & & & LC \\
\hline & Hemigrammus levis Durbin 1908 & & & \\
\hline & Hemigrammus luelingi Géry 1964 & & & $\mathrm{LC}$ \\
\hline & Hemigrammus lunatus Durbin 1918 & & & \\
\hline & Hemigrammus marginatus Ellis 1911 & & & \\
\hline & Hemigrammus megaceps Fowler 1945 & & & $\mathrm{DD}$ \\
\hline & Hemigrammus microstomus Durbin 1918 & & & \\
\hline & Hemigrammus neptunus Zarske \& Géry 2002 & & & \\
\hline & Hemigrammus newboldi (Fernández-Yépez 1949) & & & \\
\hline & Hemigrammus ocellifer (Steindachner 1882) & & & \\
\hline & Hemigrammus pulcher Ladiges 1938 & & & $\mathrm{LC}$ \\
\hline & Hemigrammus rodwayi Durbin 1909 & & & \\
\hline & Hemigrammus schmardae (Steindachner 1882) & & & \\
\hline & Hemigrammus unilineatus (Gill 1858) & & & \\
\hline & Hemigrammus vorderwinkleri Géry 1963 & & & \\
\hline & Heterocharax macrolepis Eigenmann 1912 & & & \\
\hline & Hyphessobrycon agulha Fowler 1913 & & & \\
\hline & Hyphessobrycon bentosi Durbin 1908 & & & $\mathrm{LC}$ \\
\hline & $\begin{array}{l}\text { Hyphessobrycon chiribiquete Garcia-Alzate, Lima, Taphorn, Mojica, Urbano-Bonilla \& } \\
\text { Teixeira } 2020\end{array}$ & & & \\
\hline & Hyphessobrycon copelandi Durbin 1908 & & & \\
\hline & Hyphessobrycon eques (Steindachner 1882) & & & \\
\hline & Hyphessobrycon erythrostigma (Fowler 1943) & & & \\
\hline & Hyphessobrycon frankei Zarske \& Géry 1997 & & & LC \\
\hline & Hyphessobrycon jackrobertsi Zarske 2014 & $\mathrm{x}$ & & \\
\hline & Hyphessobrycon loretoensis Ladiges 1938 & & & $\mathrm{LC}$ \\
\hline & Hyphessobrycon margitae Zarske 2016 & $x$ & & \\
\hline & Hyphessobrycon minimus Durbin 1909 & & & \\
\hline & Hyphessobrycon peruvianus Ladiges 1938 & & & LC \\
\hline & Hyphessobrycon robustulus (Cope 1870) & & & LC \\
\hline & Hyphessobrycon taphorni García-Alzate, Román-Valencia \& Ortega 2013 & & & \\
\hline & Hyphessobrycon tenuis Géry 1964 & & & $\mathrm{LC}$ \\
\hline & Jupiaba anterior (Eigenmann 1908) & & & \\
\hline & Jupiaba anteroides (Géry 1965) & & & \\
\hline & Jupiaba asymmetrica (Eigenmann 1908) & & & \\
\hline & Jupiaba scologaster (Weitzman \& Vari 1986) & & & \\
\hline & Jupiaba zonata (Eigenmann 1908) & & & \\
\hline
\end{tabular}




\begin{tabular}{|c|c|c|c|c|}
\hline Order / Family & \multirow{2}{*}{$\begin{array}{l}\text { Species } \\
\text { Knodus borki Zarske } 2008\end{array}$} & \multirow{2}{*}{$\frac{\mathrm{RD}}{\mathrm{x}}$} & \multirow[t]{2}{*}{ C } & \multirow[t]{2}{*}{ IUCN } \\
\hline & & & & \\
\hline & Knodus breviceps (Eigenmann 1908) & & & \\
\hline & Knodus gamma Géry 1972 & & & LC \\
\hline & Knodus hypopterus (Fowler 1943) & & & LC \\
\hline & Knodus megalops Myers 1929 & & & LC \\
\hline & Knodus orteguasae (Fowler 1943) & & & \\
\hline & Knodus savannensis Géry 1961 & & & \\
\hline & Knodus septentrionalis Géry 1972 & & & \\
\hline & Knodus smithi (Fowler 1913) & & & \\
\hline & Leptagoniates steindachneri Boulenger 1887 & & & \\
\hline & Microschemobrycon geisleri Géry 1973 & & & \\
\hline & Microschemobrycon melanotus (Eigenmann 1912) & & & \\
\hline & Moenkhausia agnesae Géry 1965 & & & \\
\hline & Moenkhausia atahualpiana (Fowler 1907) & & & $\mathrm{LC}$ \\
\hline & Moenkhausia barbouri Eigenmann 1908 & & & \\
\hline & Moenkhausia ceros Eigenmann 1908 & & & \\
\hline & Moenkhausia chrysargyrea (Günther 1864) & & & \\
\hline & Moenkhausia collettii (Steindachner 1882) & & & \\
\hline & Moenkhausia comma Eigenmann 1908 & & & \\
\hline & Moenkhausia copei (Steindachner 1882) & & & \\
\hline & Moenkhausia cotinho Eigenmann 1908 & & & \\
\hline & Moenkhausia dichroura (Kner 1858) & & & \\
\hline & Moenkhausia grandisquamis (Müller \& Troschel 1845) & & & \\
\hline & Moenkhausia intermedia Eigenmann 1908 & & & \\
\hline & Moenkhausia jamesi Eigenmann 1908 & & & \\
\hline & Moenkhausia latissima Eigenmann 1908 & & & \\
\hline & Moenkhausia lepidura (Kner 1858) & & & \\
\hline & Moenkhausia margitae Zarske \& Géry 2001 & & & NT \\
\hline & Moenkhausia megalops (Eigenmann 1907) & & & \\
\hline & Moenkhausia melogramma Eigenmann 1908 & & & \\
\hline & Moenkhausia mikia Marinho \& Langeani 2010 & & & \\
\hline & Moenkhausia naponis Böhlke 1958 & & & \\
\hline & Moenkhausia oligolepis (Günther 1864) & & & \\
\hline & Moenkhausia robertsi Géry 1964 & & & \\
\hline & Moenkhausia simulata (Eigenmann 1924) & & & $\mathrm{LC}$ \\
\hline & Odontostilbe ecuadorensis Bührnheim \& Malabarba 2006 & & & LC \\
\hline & Odontostilbe euspilurus (Fowler 1945) & & & \\
\hline & Odontostilbe fugitiva Cope 1870 & & & \\
\hline & Othonocheirodus eigenmanni Myers 1927 & & & LC \\
\hline & Oxybrycon parvulus Géry 1964 & & & \\
\hline & Paracheirodon innesi (Myers 1936) & & & \\
\hline & Paragoniates alburnus Steindachner 1876 & & & \\
\hline & Parecbasis cyclolepis Eigenmann 1914 & & & \\
\hline & Petitella georgiae Géry \& Boutière 1964 & & & \\
\hline & Phenacogaster capitulata Lucena \& Malabarba 2010 & & & \\
\hline & Phenacogaster megalostictus Eigenmann 1909 & & & \\
\hline & Phenacogaster pectinata (Cope 1870) & & & \\
\hline & Poptella compressa (Günther 1864) & & & \\
\hline & Priocharax pygmaeus Weitzman \& Vari 1987 & & & LC \\
\hline & Prionobrama filigera (Cope 1870) & & & \\
\hline & Prodontocharax alleni Böhlke 1953 & & & \\
\hline & Prodontocharax melanotus Pearson 1924 & & & \\
\hline & Protocheirodon pi (Vari 1978) & & & \\
\hline & Psalidodon fasciatus (Cuvier 1819) & & & \\
\hline & Rhinobrycon negrensis Myers 1944 & & & \\
\hline & Roeboides affinis (Günther 1868) & & & LC \\
\hline & Roeboides biserialis (Garman 1890) & & & \\
\hline & Roeboides myersii Fowler 1932 & & $*$ & \\
\hline & Scopaeocharax atopodus (Böhlke 1958) & & & $\mathrm{LC}$ \\
\hline & Scopaeocharax rhinodus (Böhlke 1958) & & & LC \\
\hline & Serrapinnus heterodon (Eigenmann 1915) & & & \\
\hline & Serrapinnus piaba (Lütken 1875) & & & \\
\hline
\end{tabular}




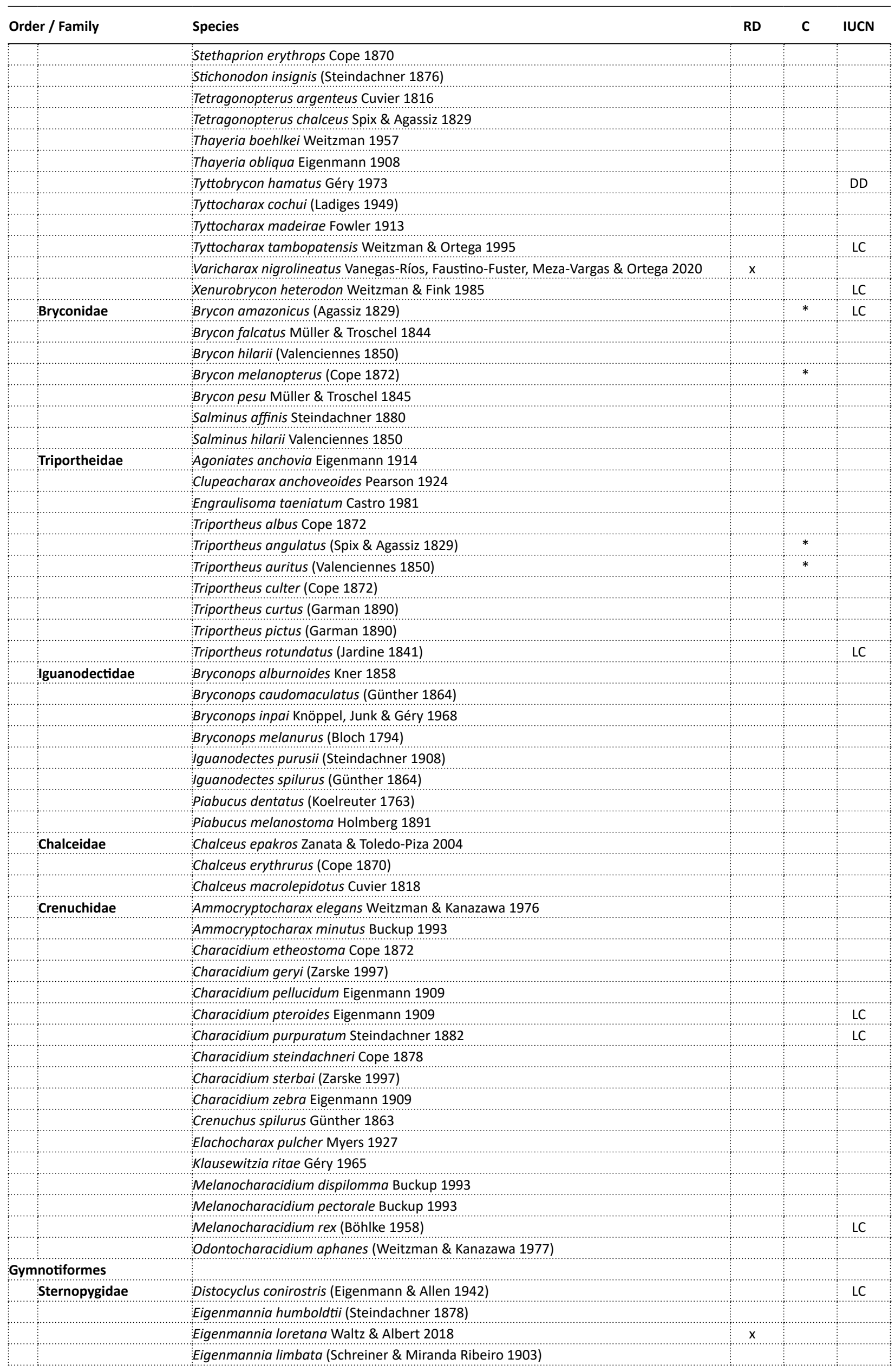




\begin{tabular}{|c|c|c|c|c|}
\hline Order / Family & Species & RD & C & IUCN \\
\hline & Eigenmannia macrops (Boulenger 1897) & & & \\
\hline & Eigenmannia virescens (Valenciennes 1836) & & & \\
\hline & Rhabdolichops caviceps (Fernández-Yépez 1968) & & & \\
\hline & Rhabdolichops eastwardi Lundberg \& Mago-Leccia 1986 & & & \\
\hline & Rhabdolichops electrogrammus Lundberg \& Mago-Leccia 1986 & & & \\
\hline & Rhabdolichops troscheli (Kaup 1856) & & & \\
\hline & Sternopygus macrurus (Bloch \& Schneider 1801) & & & \\
\hline Apteronotidae & Adontosternarchus balaenops (Cope 1878) & & & \\
\hline & Adontosternarchus clarkae Mago-Leccia, Lundberg \& Baskin 1985 & & & \\
\hline & Adontosternarchus nebulosus Lundberg \& Cox Fernandes 2007 & & & \\
\hline & Adontosternarchus sachsi (Peters 1877) & & & \\
\hline & Apteronotus albifrons (Linnaeus 1766) & & & \\
\hline & Apteronotus bonapartii (Castelnau 1855) & & & \\
\hline & Compsaraia samueli Albert \& Crampton 2009 & & & \\
\hline & Melanosternarchus amaru Bernt, Crampton, Orfinger \& Albert 2018 & & & \\
\hline & Orthosternarchus tamandua (Boulenger 1898) & & & \\
\hline & Parapteronotus hasemani (Ellis 1913) & & & \\
\hline & Platyurosternarchus macrostoma (Günther 1870) & & & LC \\
\hline & Porotergus duende de Santana \& Crampton 2010 & & & \\
\hline & Porotergus gimbeli Ellis 1912 & & & \\
\hline & Sternarchella calhamazon Lundberg, Cox Fernandes, Campos-da-Paz \& Sullivan 2013 & & & \\
\hline & Sternarchella duccis (Lundberg, Cox Fernandes \& Albert 1996) & & & \\
\hline & Sternarchella orthos Mago-Leccia 1994 & & & \\
\hline & Sternarchella raptor (Lundberg, Cox Fernandes \& Albert 1996) & & & \\
\hline & Sternarchella rex Evans, Crampton \& Albert 2017 & & & \\
\hline & Sternarchella schotti (Steindachner 1868) & & & \\
\hline & Sternarchella sima Starks 1913 & & & \\
\hline & Sternarchogiton nattereri (Steindachner 1868) & & & \\
\hline & Sternarchogiton porcinum Eigenmann \& Allen 1942 & & & \\
\hline & Sternarchorhamphus muelleri (Steindachner 1881) & & & \\
\hline & Sternarchorhynchus cramptoni de Santana \& Vari 2010 & & & \\
\hline & Sternarchorhynchus goeldii de Santana \& Vari 2010 & & & \\
\hline & Sternarchorhynchus montanus de Santana \& Vari 2010 & & & \\
\hline & Sternarchorhynchus mormyrus (Steindachner 1868) & & & LC \\
\hline & Sternarchorhynchus oxyrhynchus (Müller \& Troschel 1849) & & & \\
\hline & Sternarchorhynchus retzeri de Santana \& Vari 2010 & & & \\
\hline & Sternarchorhynchus stewarti de Santana \& Vari 2010 & & & LC \\
\hline & Tenebrosternarchus preto (de Santana \& Crampton 2007) & & & \\
\hline Rhamphichthyidae & Gymnorhamphichthys hypostomus Ellis 1912 & & & \\
\hline & Gymnorhamphichthys rondoni (Miranda Ribeiro 1920) & & & \\
\hline & Hypopygus lepturus Hoedeman 1962 & & & \\
\hline & Hypopygus ortegai de Santana \& Crampton 2011 & $\mathrm{x}$ & & $\mathrm{LC}$ \\
\hline & Rhamphichthys lineatus Castelnau 1855 & & & \\
\hline & Rhamphichthys pantherinus Castelnau 1855 & & & \\
\hline & Rhamphichthys rostratus (Linnaeus 1766) & & & \\
\hline & Steatogenys duidae (LaMonte 1929) & & & \\
\hline & Steatogenys elegans (Steindachner 1880) & & & LC \\
\hline Hypopomidae & Brachyhypopomus beebei (Schultz 1944) & & & \\
\hline & Brachyhypopomus benjamini Crampton, de Santana, Waddell \& Lovejoy 2017 & $x$ & & \\
\hline & Brachyhypopomus bennetti Sullivan, Zuanon \& Cox Fernandes 2013 & & & \\
\hline & Brachyhypopomus brevirostris (Steindachner 1868) & & & \\
\hline & Brachyhypopomus flavipomus Crampton, de Santana, Waddell \& Lovejoy 2017 & & & \\
\hline & Brachyhypopomus hamiltoni Crampton, de Santana, Waddell \& Lovejoy 2017 & & & \\
\hline & Brachyhypopomus pinnicaudatus (Hopkins, Comfort, Bastian \& Bass 1990) & & & \\
\hline & Brachyhypopomus regani Crampton, de Santana, Waddell \& Lovejoy 2017 & & & \\
\hline & Brachyhypopomus sullivani Crampton, de Santana, Waddell \& Lovejoy 2017 & & & \\
\hline & Brachyhypopomus verdii Crampton, de Santana, Waddell \& Lovejoy 2017 & & & \\
\hline & Brachyhypopomus walteri Sullivan, Zuanon \& Cox Fernandes 2013 & & & \\
\hline & Microsternarchus bilineatus Fernández-Yépez 1968 & & & \\
\hline Gymnotidae & Electrophorus electricus (Linnaeus 1766) & & & LC \\
\hline & Electrophorus multivalvulus Nakashima 1941 & & & \\
\hline & Gymnotus anguillaris Hoedeman 1962 & & & \\
\hline
\end{tabular}




\begin{tabular}{|c|c|c|c|c|}
\hline Order / Family & Species & RD & C & IUCN \\
\hline & Gymnotus carapo Linnaeus 1758 & & & LC \\
\hline & Gymnotus chaviro Maxime \& Albert 2009 & & & LC \\
\hline & Gymnotus coatesi LaMonte 1935 & & & \\
\hline & Gymnotus curupira Crampton, Thorsen \& Albert 2005 & & & \\
\hline & Gymnotus javari Albert, Crampton \& Hagedorn 2003 & & & \\
\hline & Gymnotus jonasi Albert \& Crampton 2001 & & & LC \\
\hline & Gymnotus tigre Albert \& Crampton 2003 & & & \\
\hline & Gymnotus ucamara Crampton, Lovejoy \& Albert 2003 & $\mathrm{x}$ & & \\
\hline & Gymnotus varzea Crampton, Thorsen \& Albert 2005 & & & \\
\hline \multicolumn{5}{|l|}{ Siluriformes } \\
\hline Doradidae & Acanthodoras cataphractus (Linnaeus 1758) & & & \\
\hline & Acanthodoras spinosissimus (Eigenmann \& Eigenmann 1888) & & & \\
\hline & Agamyxis pectinifrons (Cope 1870) & & & \\
\hline & Amblydoras affinis (Kner 1855) & & & \\
\hline & Amblydoras monitor (Cope 1872) & & & LC \\
\hline & Amblydoras nauticus (Cope 1874) & & & LC \\
\hline & Anadoras grypus (Cope 1872) & & & LC \\
\hline & Hassar orestis (Steindachner 1875) & & & \\
\hline & Hemidoras morrisi Eigenmann 1925 & & & \\
\hline & Hemidoras stenopeltis (Kner 1855) & & & \\
\hline & Hemidoras stuebelii (Steindachner 1882) & & & \\
\hline & Hypodoras forficulatus Eigenmann 1925 & & & DD \\
\hline & Leptodoras acipenserinus (Günther 1868) & & & \\
\hline & Leptodoras cataniai Sabaj Pérez 2005 & & & \\
\hline & Leptodoras copei (Fernández-Yépez 1968) & & & \\
\hline & Leptodoras juruensis Boulenger 1898 & & & \\
\hline & Leptodoras myersi Böhlke 1970 & & & \\
\hline & Lithodoras dorsalis (Valenciennes 1840) & & & \\
\hline & Megalodoras uranoscopus (Eigenmann \& Eigenmann 1888) & & $*$ & \\
\hline & Nemadoras elongatus (Boulenger 1898) & & & \\
\hline & Nemadoras hemipeltis (Eigenmann 1925) & & & \\
\hline & Nemadoras humeralis (Kner 1855) & & & \\
\hline & Ossancora asterophysa Birindelli \& Sabaj Pérez 2011 & & & \\
\hline & Ossancora eigenmanni (Boulenger 1895) & & & \\
\hline & Ossancora punctata (Kner 1855) & & & \\
\hline & Oxydoras niger (Valenciennes 1821) & & $*$ & \\
\hline & Physopyxis ananas Sousa \& Rapp Py-Daniel 2005 & & & \\
\hline & Physopyxis lyra Cope 1872 & & & \\
\hline & Platydoras armatulus (Valenciennes 1840) & & & \\
\hline & Platydoras costatus (Linnaeus 1758) & & & \\
\hline & Pterodoras granulosus (Valenciennes 1821) & & * & \\
\hline & Rhinodoras boehlkei Glodek, Whitmire \& Orcés V. 1976 & & & LC \\
\hline & Rhynchodoras woodsi Glodek 1976 & & & \\
\hline & Scorpiodoras sp. & & & \\
\hline & Tenellus cristinae (Sabaj Pérez, Arce H., Sousa \& Birindelli 2014) & & & \\
\hline & Tenellus ternetzi (Eigenmann 1925) & & & \\
\hline & Tenellus trimaculatus (Boulenger 1898) & & & \\
\hline & Trachydoras gepharti Sabaj Pérez \& Arce H. 2017 & & & \\
\hline & Trachydoras nattereri (Steindachner 1881) & & & \\
\hline & Trachydoras steindachneri (Perugia 1897) & & & \\
\hline \multirow[t]{12}{*}{ Auchenipteridae } & Ageneiosus inermis (Linnaeus 1766) & & $*$ & \\
\hline & Ageneiosus ucayalensis Castelnau 1855 & & & \\
\hline & Ageneiosus uranophthalmus Ribeiro \& Rapp Py-Daniel 2010 & & & \\
\hline & Auchenipterichthys coracoideus (Eigenmann \& Allen 1942) & & & LC \\
\hline & Auchenipterichthys longimanus (Günther 1864) & & & \\
\hline & Auchenipterichthys thoracatus (Kner 1858) & & & \\
\hline & Auchenipterus ambyiacus Fowler 1915 & & & \\
\hline & Auchenipterus brachyurus (Cope 1878) & & & \\
\hline & Auchenipterus fordicei Eigenmann \& Eigenmann 1888 & & & \\
\hline & Auchenipterus nuchalis (Spix \& Agassiz 1829) & & $*$ & \\
\hline & Balroglanis macracanthus (Soares-Porto 2000) & & & \\
\hline & Centromochlus existimatus Mees 1974 & & & \\
\hline
\end{tabular}




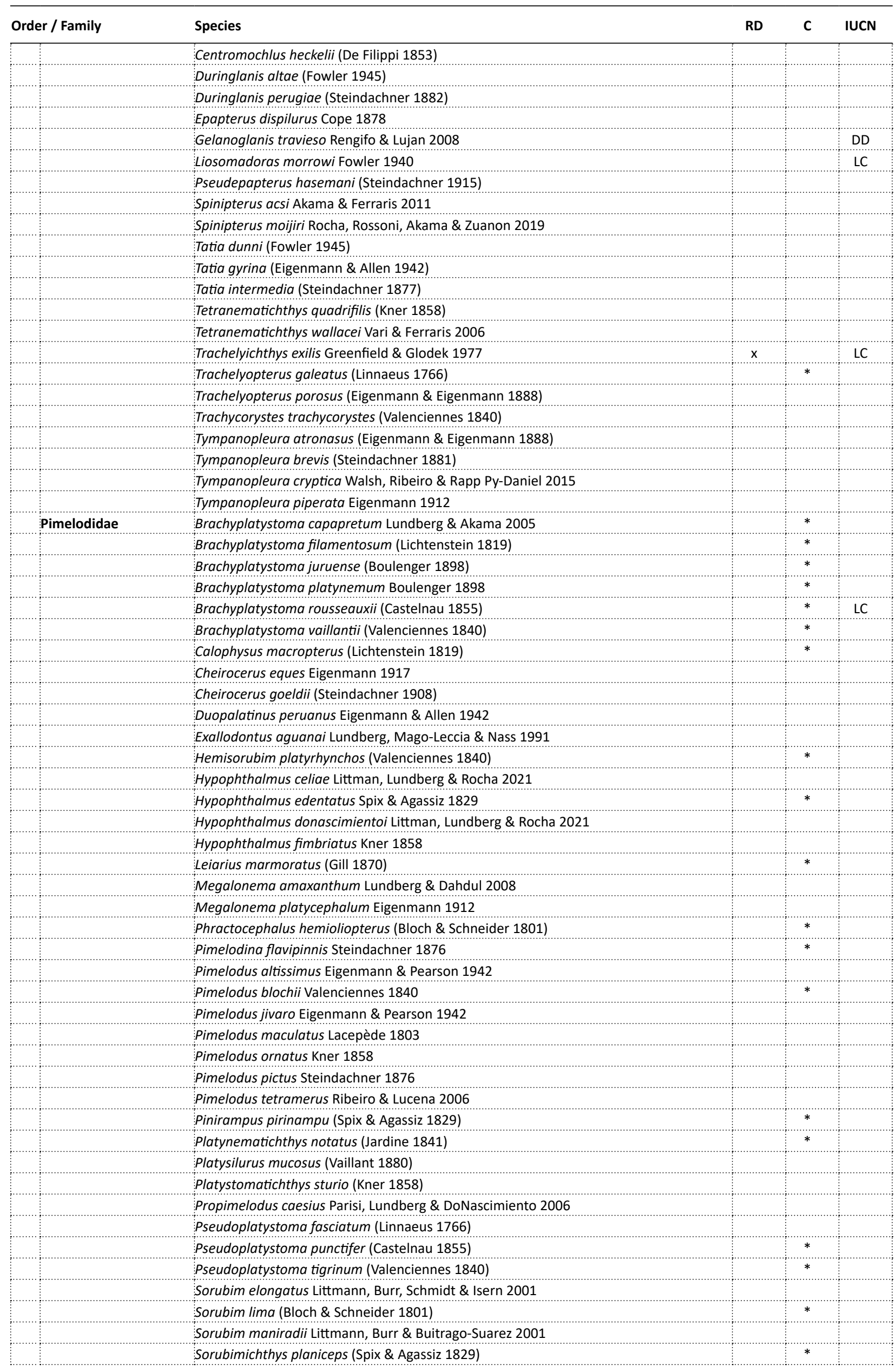




\begin{tabular}{|c|c|c|c|c|}
\hline Order / Family & \multirow{2}{*}{$\begin{array}{l}\text { Species } \\
\text { Zungaro zungaro (Humboldt 1821) }\end{array}$} & \multirow[t]{2}{*}{ RD } & \multirow{2}{*}{ C } & \multirow[t]{2}{*}{ IUCN } \\
\hline & & & & \\
\hline Pseudopimelodidae & Batrochoglanis raninus (Valenciennes 1840) & & & \\
\hline & Microglanis poecilus Eigenmann 1912 & & & \\
\hline & Microglanis zonatus Eigenmann \& Allen 1942 & & & $\mathrm{LC}$ \\
\hline & Pseudopimelodus bufonius (Valenciennes 1840) & & & \\
\hline & Rhyacoglanis pulcher (Boulenger 1887) & & & \\
\hline Heptapteridae & Cetopsorhamdia hidalgoi Faustino-Fuster \& Souza 2021 & & & \\
\hline & Chasmocranus peruanus Eigenmann \& Pearson 1942 & & & DD \\
\hline & Gladioglanis conquistador Lundberg, Bornbusch \& Mago-Leccia 1991 & & & \\
\hline & Goeldiella eques (Müller \& Troschel 1849) & & & \\
\hline & Imparfinis guttatus (Pearson 1924) & & & \\
\hline & Imparfinis pseudonemacheir Mees \& Cala 1989 & & & \\
\hline & Mastiglanis yaguas Faustino-Fuster \& Ortega 2020 & $\mathrm{x}$ & & \\
\hline & Myoglanis koepckei Chang 1999 & & & \\
\hline & Nemuroglanis lanceolatus Eigenmann \& Eigenmann 1889 & & & \\
\hline & Pariolius armillatus Cope 1872 & & & \\
\hline & Phenacorhamdia sp. & & & \\
\hline & Pimelodella buckleyi (Boulenger 1887) & & & $\mathrm{DD}$ \\
\hline & Pimelodella cristata (Müller \& Troschel 1849) & & & LC \\
\hline & Pimelodella cyanostigma (Cope 1870) & & & $\mathrm{DD}$ \\
\hline & Pimelodella gracilis (Valenciennes 1835) & & & \\
\hline & Pimelodella hasemani Eigenmann 1917 & & & \\
\hline & Pimelodella lateristriga (Lichtenstein 1823) & & & \\
\hline & Pimelodella serrata Eigenmann 1917 & & & \\
\hline & Rhamdia cf. quelen & & & \\
\hline Cetopsidae & Cetopsis candiru Spix \& Agassiz 1829 & & & \\
\hline & Cetopsis coecutiens (Lichtenstein 1819) & & & \\
\hline & Cetopsis montana Vari, Ferraris \& de Pinna 2005 & & & $\mathrm{LC}$ \\
\hline & Cetopsis oliveirai (Lundberg \& Rapp Py-Daniel 1994) & & & \\
\hline & Cetopsis parma Oliveira, Vari \& Ferraris 2001 & & & \\
\hline & Cetopsis plumbea Steindachner 1882 & & & \\
\hline & Denticetopsis seducta Vari, Ferraris \& de Pinna 2005 & & & \\
\hline & Helogenes marmoratus Günther 1863 & & & \\
\hline Aspredinidae & Amaralia hypsiura (Kner 1855) & & & \\
\hline & Bunocephalus aleuropsis Cope 1870 & & & \\
\hline & Bunocephalus coracoideus (Cope 1874) & & & $\mathrm{LC}$ \\
\hline & Bunocephalus knerii Steindachner 1882 & & & LC \\
\hline & Bunocephalus verrucosus (Walbaum 1792) & & & \\
\hline & Pseudobunocephalus amazonicus (Mees 1989) & & & \\
\hline & Pseudobunocephalus bifidus (Eigenmann 1942) & & & \\
\hline & Pterobunocephalus depressus (Haseman 1911) & & & \\
\hline & Pterobunocephalus dolichurus (Delsman 1941) & & & \\
\hline & Xyliphius sofiae Sabaj Pérez, Carvalho \& Reis 2017 & $\mathrm{x}$ & & \\
\hline Trichomycteridae & Acanthopoma annectens Lütken 1892 & & & \\
\hline & Apomatoceros alleni Eigenmann 1922 & & & \\
\hline & Henonemus macrops (Steindachner 1882) & & & \\
\hline & Henonemus punctatus (Boulenger 1887) & & & \\
\hline & Ituglanis amazonicus (Steindachner 1882) & & & \\
\hline & Megalocentor echthrus de Pinna \& Britski 1991 & & & \\
\hline & Ochmacanthus reinhardtii (Steindachner 1882) & & & \\
\hline & Pareiodon microps Kner 1855 & & & \\
\hline & Plectrochilus diabolicus (Myers 1927) & & & \\
\hline & Potamoglanis hasemani (Eigenmann 1914) & & & \\
\hline & Pseudostegophilus nemurus (Günther 1869) & & & \\
\hline & Schultzichthys bondi (Myers 1942) & & & \\
\hline & Trichomycterus cf. rivulatus & & & \\
\hline & Tridensimilis brevis (Eigenmann \& Eigenmann 1889) & & & \\
\hline & Tridentopsis pearsoni Myers 1925 & & & \\
\hline & Vandellia cirrhosa Valenciennes 1846 & & & \\
\hline & Vandellia sanguinea Eigenmann 1917 & & & \\
\hline Callichthyidae & Callichthys callichthys (Linnaeus 1758) & & & \\
\hline & Corydoras acutus Cope 1872 & & & LC \\
\hline
\end{tabular}




\begin{tabular}{|c|c|c|c|c|}
\hline Order / Family & Species & RD & C & IUCN \\
\hline & Corydoras aeneus (Gill 1858) & & & \\
\hline & Corydoras agassizii Steindachner 1876 & & & \\
\hline & Corydoras ambiacus Cope 1872 & & & \\
\hline & Corydoras amphibelus Cope 1872 & & & LC \\
\hline & Corydoras arcuatus Elwin 1938 & & & \\
\hline & Corydoras armatus (Günther 1868) & & & \\
\hline & Corydoras atropersonatus Weitzman \& Nijssen 1970 & & & DD \\
\hline & Corydoras copei Nijssen \& Isbrücker 1986 & & & LC \\
\hline & Corydoras coriatae Burgess 1997 & & & LC \\
\hline & Corydoras elegans Steindachner 1876 & & & \\
\hline & Corydoras eques Steindachner 1876 & & & \\
\hline & Corydoras fowleri Böhlke 1950 & & & LC \\
\hline & Corydoras lamberti Nijssen \& Isbrücker 1986 & & & LC \\
\hline & Corydoras leopardus Myers 1933 & & & \\
\hline & Corydoras leucomelas Eigenmann \& Allen 1942 & & & LC \\
\hline & Corydoras loretoensis Nijssen \& Isbrücker 1986 & & & LC \\
\hline & Corydoras melini Lönnberg \& Rendahl 1930 & & & LC \\
\hline & Corydoras multiradiatus (Orcés V. 1960) & & & LC \\
\hline & Corydoras napoensis Nijssen \& Isbrücker 1986 & & & LC \\
\hline & Corydoras ortegai Britto, Lima \& Hidalgo 2007 & & & LC \\
\hline & Corydoras pastazensis Weitzman 1963 & & & LC \\
\hline & Corydoras pygmaeus Knaack 1966 & & & \\
\hline & Corydoras rabauti LaMonte 1941 & & & \\
\hline & Corydoras reticulatus Fraser-Brunner 1938 & & & \\
\hline & Corydoras semiaquilus Weitzman 1964 & & & \\
\hline & Corydoras sodalis Nijssen \& Isbrücker 1986 & & & \\
\hline & Corydoras splendens (Castelnau 1855) & & & \\
\hline & Corydoras stenocephalus Eigenmann \& Allen 1942 & & & LC \\
\hline & Corydoras sychri Weitzman 1960 & $x$ & & LC \\
\hline & Corydoras trilineatus Cope 1872 & & & \\
\hline & Corydoras weitzmani Nijssen 1971 & & & LC \\
\hline & Corydoras zygatus Eigenmann \& Allen 1942 & & & LC \\
\hline & Dianema longibarbis Cope 1872 & & $*$ & \\
\hline & Hoplosternum littorale (Hancock 1828) & & & \\
\hline & Lepthoplosternum altamazonicum Reis 1997 & & & LC \\
\hline & Lepthoplosternum ucamara Reis \& Kaefer 2005 & & & \\
\hline & Megalechis picta (Müller \& Troschel 1849) & & & \\
\hline & Megalechis thoracata (Valenciennes 1840) & & & \\
\hline Loricariidae & Acanthicus adonis Isbrücker \& Nijssen 1988 & & & \\
\hline & Ancistrus alga (Cope 1872) & & & \\
\hline & Ancistrus hoplogenys (Günther 1864) & & & \\
\hline & Ancistrus malacops (Cope 1872) & & & LC \\
\hline & Ancistrus sericeus (Cope 1872) & & & LC \\
\hline & Ancistrus tamboensis Fowler 1945 & & & LC \\
\hline & Ancistrus variolus (Cope 1872) & & & DD \\
\hline & Aphanotorulus emarginatus (Valenciennes 1840) & & $*$ & \\
\hline & Aphanotorulus horridus (Kner 1854) & & & \\
\hline & Aphanotorulus phrixosoma (Fowler 1940) & $x$ & & \\
\hline & Aphanotorulus unicolor (Steindachner 1908) & & & \\
\hline & Chaetostoma lineopunctatum Eigenmann \& Allen 1942 & & & LC \\
\hline & Farlowella amazonum (Günther 1864) & & & \\
\hline & Farlowella knerii (Steindachner 1882) & & & LC \\
\hline & Farlowella nattereri Steindachner 1910 & & & \\
\hline & Farlowella odontotumulus Retzer \& Page 1997 & & & \\
\hline & Farlowella oxyrryncha (Kner 1853) & & & \\
\hline & Farlowella smithi Fowler 1913 & & & \\
\hline & Hemiodontichthys acipenserinus (Kner 1853) & & & \\
\hline & Hypoptopoma brevirostratum Aquino \& Schaefer 2010 & & & \\
\hline & Hypoptopoma gulare Cope 1878 & & & \\
\hline & Hypoptopoma psilogaster Fowler 1915 & & & \\
\hline & Hypoptopoma steindachneri Boulenger 1895 & & & \\
\hline & Hypoptopoma thoracatum Günther 1868 & & & \\
\hline
\end{tabular}




\begin{tabular}{|c|c|c|c|c|}
\hline \multirow{2}{*}{ Order / Family } & \multirow{2}{*}{$\begin{array}{l}\text { Species } \\
\text { Hypostomus carinatus (Steindachner 1881) }\end{array}$} & \multirow[t]{2}{*}{ RD } & \multirow[t]{2}{*}{ C } & \multirow[t]{2}{*}{ IUCN } \\
\hline & & & & \\
\hline & Hypostomus cochliodon Kner 1854 & & & \\
\hline & Hypostomus ericius Armbruster 2003 & & & $\mathrm{LC}$ \\
\hline & Hypostomus fonchii Weber \& Montoya-Burgos 2002 & & & LC \\
\hline & Hypostomus hemicochliodon Armbruster 2003 & & & \\
\hline & Hypostomus levis (Pearson 1924) & & & DD \\
\hline & Hypostomus niceforoi (Fowler 1943) & & & DD \\
\hline & Hypostomus oculeus (Fowler 1943) & & & DD \\
\hline & Hypostomus pyrineusi (Miranda Ribeiro 1920) & & & \\
\hline & Lamontichthys filamentosus (LaMonte 1935) & & & \\
\hline & Lasiancistrus heteracanthus (Günther 1869) & & & LC \\
\hline & Lasiancistrus schomburgkii (Günther 1864) & & & LC \\
\hline & Limatulichthys griseus (Eigenmann 1909) & & & \\
\hline & Limatulichthys petleyi (Fowler 1940) & & & \\
\hline & Loricaria cataphracta Linnaeus 1758 & & & \\
\hline & Loricaria clavipinna Fowler 1940 & & & \\
\hline & Loricaria similima Regan 1904 & & & \\
\hline & Loricariichthys acutus (Valenciennes 1840) & & & \\
\hline & Loricariichthys chanjoo (Fowler 1940) & & & DD \\
\hline & Loricariichthys hauxwelli Fowler 1915 & & & LC \\
\hline & Loricariichthys maculatus (Bloch 1794) & & & \\
\hline & Loricariichthys nudirostris (Kner 1853) & & & \\
\hline & Loricariichthys stuebelii (Steindachner 1882) & & & \\
\hline & Loricariichthys ucayalensis Regan 1913 & & & LC \\
\hline & Nannoptopoma spectabile (Eigenmann 1914) & & & \\
\hline & Nannoptopoma sternoptychum Schaefer 1996 & & & \\
\hline & Otocinclus batmani Lehmann A. 2006 & & & \\
\hline & Otocinclus cocama Reis 2004 & $\mathrm{x}$ & & EN \\
\hline & Otocinclus huaorani Schaefer 1997 & & & LC \\
\hline & Otocinclus macrospilus Eigenmann \& Allen 1942 & & & LC \\
\hline & Otocinclus vestitus Cope 1872 & & & \\
\hline & Otocinclus vittatus Regan 1904 & & & \\
\hline & Oxyropsis carinata (Steindachner 1879) & & & \\
\hline & Oxyropsis wrightiana Eigenmann \& Eigenmann 1889 & & & LC \\
\hline & Panaqolus changae (Chockley \& Armbruster 2002) & $\mathrm{x}$ & & LC \\
\hline & Panaqolus dentex (Günther 1868) & & & LC \\
\hline & Panaqolus gnomus (Schaefer \& Stewart 1993) & & & LC \\
\hline & Panaqolus nocturnus (Schaefer \& Stewart 1993) & & & LC \\
\hline & Panaque bathyphilus Lujan \& Chamon 2008 & & & \\
\hline & Panaque schaeferi Lujan, Hidalgo \& Stewart 2010 & & & \\
\hline & Peckoltia brevis (LaMonte 1935) & & & \\
\hline & Peckoltia vittata (Steindachner 1881) & & & \\
\hline & Peckoltichthys bachi (Boulenger 1898) & & & \\
\hline & Planiloricaria cryptodon (Isbrücker 1971) & & & \\
\hline & Pseudohemiodon apithanos Isbrücker \& Nijssen 1978 & & & LC \\
\hline & Pseudohemiodon lamina (Günther 1868) & & & LC \\
\hline & Pseudorinelepis genibarbis (Valenciennes 1840) & & * & \\
\hline & Pterosturisoma microps (Eigenmann \& Allen 1942) & & & \\
\hline & Pterygoplichthys gibbiceps (Kner 1854) & & & \\
\hline & Pterygoplichthys pardalis (Castelnau 1855) & & $*$ & \\
\hline & Pterygoplichthys punctatus (Kner 1854) & & & \\
\hline & Pterygoplichthys scrophus (Cope 1874) & $\mathrm{x}$ & & LC \\
\hline & Rhadinoloricaria bahuaja (Chang \& Castro 1999) & & & \\
\hline & Rhadinoloricaria macromystax (Günther 1869) & & & DD \\
\hline & Rhadinoloricaria ommation (Nijssen \& Isbrücker 1988) & & & \\
\hline & Rhadinoloricaria rhami (Isbrücker \& Nijssen 1983) & & & \\
\hline & Rineloricaria konopickyi (Steindachner 1879) & & & \\
\hline & Rineloricaria lanceolata (Günther 1868) & & & \\
\hline & Rineloricaria morrowi Fowler 1940 & & & LC \\
\hline & Rineloricaria phoxocephala (Eigenmann \& Eigenmann 1889) & & & \\
\hline & Rineloricaria wolfei Fowler 1940 & $\mathrm{x}$ & & LC \\
\hline & Spatuloricaria evansii (Boulenger 1892) & & & LC \\
\hline
\end{tabular}




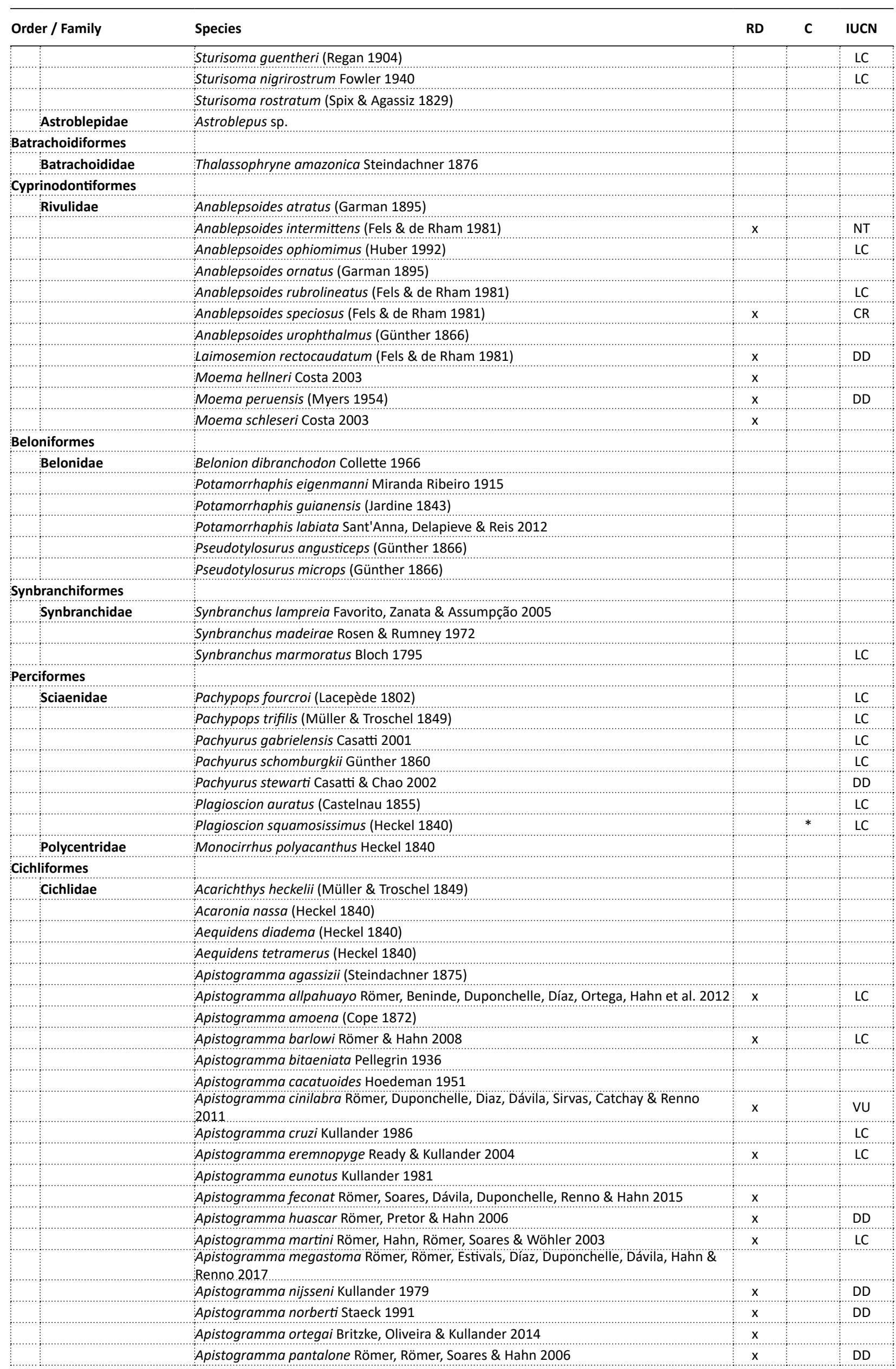




\begin{tabular}{|c|c|c|c|c|}
\hline Order / Family & \multirow{2}{*}{$\begin{array}{l}\text { Species } \\
\text { Apistogramma paulmuelleri Römer, Beninde, Duponchelle, Dávila, Vela Díaz, \& Renno } \\
2013\end{array}$} & \multirow{2}{*}{$\frac{\mathrm{RD}}{\mathrm{x}}$} & \multirow[t]{2}{*}{ c } & \multirow{2}{*}{$\frac{\text { IUCN }}{\mathrm{DD}}$} \\
\hline & & & & \\
\hline & Apistogramma payaminonis Kullander 1986 & & & DD \\
\hline & Apistogramma rositae Römer, Römer \& Hahn 2006 & $x$ & & DD \\
\hline & Apistogramma wolli Römer, Soares, Dávila, Duponchelle, Renno \& Hahn 2015 & & & \\
\hline & Apistogrammoides pucallpaensis Meinken 1965 & & & \\
\hline & Astronotus ocellatus (Agassiz 1831) & & $*$ & \\
\hline & Biotodoma cupido (Heckel 1840) & & & \\
\hline & Bujurquina apoparuana Kullander 1986 & & & LC \\
\hline & Bujurquina hophrys Kullander 1986 & & & LC \\
\hline & Bujurquina huallagae Kullander 1986 & & & LC \\
\hline & Bujurquina labiosa Kullander 1986 & & & LC \\
\hline & Bujurquina moriorum Kullander 1986 & & & LC \\
\hline & Bujurquina ortegai Kullander 1986 & & & DD \\
\hline & Bujurquina pardus Arbour, Barriga Salazar \& López-Fernández 2014 & & & DD \\
\hline & Bujurquina peregrinabunda Kullander 1986 & & & \\
\hline & Bujurquina robusta Kullander 1986 & & & DD \\
\hline & Bujurquina syspilus (Cope 1872) & & & LC \\
\hline & Chaetobranchus flavescens Heckel 1840 & & $*$ & \\
\hline & Cichla monoculus Spix \& Agassiz 1831 & & $*$ & \\
\hline & Cichlasoma amazonarum Kullander 1983 & & & \\
\hline & Crenicara punctulata (Günther 1863) & & & \\
\hline & Crenicichla anthurus Cope 1872 & & & LC \\
\hline & Crenicichla cincta Regan 1905 & & * & LC \\
\hline & Crenicichla cyanonotus Cope 1870 & & & \\
\hline & Crenicichla johanna Heckel 1840 & & $*$ & \\
\hline & Crenicichla lucius Cope 1870 & & & \\
\hline & Crenicichla proteus Cope 1872 & & & \\
\hline & Crenicichla reticulatus (Heckel 1840) & & & \\
\hline & Crenicichla sedentaria Kullander 1986 & & & LC \\
\hline & Crenicichla semicincta Steindachner 1892 & & & \\
\hline & Heroina isonycterina Kullander 1996 & & & LC \\
\hline & Heros efasciatus Heckel 1840 & & * & \\
\hline & Hypselecara temporalis (Günther 1862) & & $*$ & \\
\hline & Laetacara flavilabris (Cope 1870) & & & \\
\hline & Laetacara thayeri (Steindachner 1875) & & & \\
\hline & Mesonauta festivus (Heckel 1840) & & & \\
\hline & Mesonauta insignis (Heckel 1840) & & & \\
\hline & Mesonauta mirificus Kullander \& Silfvergrip 1991 & & & LC \\
\hline & Pterophyllum scalare (Schultze 1823) & & & \\
\hline & Satanoperca jurupari (Heckel 1840) & & * & \\
\hline & Symphysodon tarzoo Lyons 1959 & & & \\
\hline & Tahuantinsuyoa macantzatza Kullander 1986 & & & DD \\
\hline \multicolumn{5}{|l|}{ Carangiformes } \\
\hline Achiridae & Achirus achirus (Linnaeus 1758) & & & LC \\
\hline & Apionichthys finis (Eigenmann 1912) & & & \\
\hline & Apionichthys nattereri (Steindachner 1876) & & & LC \\
\hline & Apionichthys seripierriae Ramos 2003 & & & \\
\hline & Hypoclinemus mentalis (Günther 1862) & & & \\
\hline \multicolumn{5}{|l|}{ Tetraodontiformes } \\
\hline Tetraodontidae & Colomesus asellus (Müller \& Troschel 1849) & & & \\
\hline
\end{tabular}

